\title{
Estimated incident cost savings in shipping due to inspections
}

\author{
Sabine Knapp ${ }^{1}$, Govert Bijwaard ${ }^{2}$ and Christiaan Heij ${ }^{3}$
}

Econometric Institute Report 2010-28

\begin{abstract}
The effectiveness of safety inspections has been analysed from various angles, but until now, relatively little attention has been given to translate risk reduction into incident cost savings. This paper quantifies estimated cost savings based on port state control inspections and industry vetting inspections. It is based on a unique dataset of 515,194 ship arrivals and inspections from the United States of America and Australia, and inspections of three industry vetting inspection regimes, for the time period 2002 to 2007 . The risk reducing effect of inspections is estimated by means of duration models, in terms of inspection gains based on the probability of survival. The results suggest average total estimated cost savings in the range of USD 74 to 192 thousand (median USD 19 to 46 thousand) owing to reduced risk of total loss due to a port state control inspection. Cost savings for industry inspections are found to be even higher, especially for tankers. The savings vary by type, age and size of the ship. The benefits of an inspection are in general larger for older and larger vessels, and also for vessels with undefined flags and unknown classification societies. As inspection costs are relatively low in comparison to potential cost savings, the results underline the importance in determining high risk ships to prevent costs due to total loss of ships.
\end{abstract}

\section{Keywords}

Maritime safety, ship inspection, duration analysis

\footnotetext{
${ }^{1}$ Econometric Institute, Erasmus School of Economics, Erasmus University Rotterdam, P.O. Box 1738, 3000 DR Rotterdam, The Netherlands. E-mail address: knapp@ese.eur.nl

${ }^{2}$ Netherlands Interdisciplinary Demographic Institute (NIDI), Lange Houtstraat 19, P.O. Box 11650, 2502 AR The Hague, The Netherlands, e-mail address: bijwaard@nidi.nl

3 Econometric Institute, Erasmus School of Economics, Erasmus University Rotterdam, P.O. Box 1738, 3000 DR Rotterdam, The Netherlands. E-mail address: heij@ese.eur.nl
} 


\section{Introduction}

World trade depends heavily on the services of the shipping industry. According to the United Nations Conference on Trade and Development (UNCTAD) [1], 80\% of the volume of world merchandise trade is carried by sea, which translates into a total of 8,168 million of tons of cargo or a total of 32.7 trillion ton-miles ${ }^{4}$ for 2008 . Due to an increase in world trade, the world fleet has grown considerably in terms of numbers and size of ships, by approximately $16 \%$ [2] over the last ten years (in terms of numbers of vessels). Nonetheless, the incident rate of ship-accidents is relatively low, according to Bijwaard and Knapp [3]. A minimum safety level of ships is maintained by the complex regulatory framework of the International Maritime Organization (IMO), with over 50 conventions regulating all aspects of international shipping. There are, however, some loopholes in the system. Especially, substandard shipping activities can create distortion of competition among ship owners and can also lead to incidents ${ }^{5}$. Shipping incidents tend to carry very high economic costs, due to the large asset values and the high operational risks involved in shipping.

Enforcement of the regulatory framework is the duty of sovereign flag states. This is followed by a second line of defense, port state control inspections, which comprise both mandatory and non-mandatory inspections. Mandatory inspections or surveys are normally performed by classification societies ${ }^{6}$ on behalf of the flag state administrations, in order to issue and maintain mandatory ship certificates required by the legislative framework of IMO. Non-mandatory inspections can be divided into inspections performed by port state control and those performed by industry. Industry inspections are performed by vetting inspection regimes where compliance is enhanced due to the connection of the inspection with the ability to obtain cargo from charterers. If a vessel does not obtain an acceptable inspection report, it will not obtain cargo. We refer to Knapp and Franses [4] for a more detailed discussion on the various types of inspections. For the purpose of this article, we use vetting inspections performed on dry bulk carriers $\left(\right.$ RightShip $\left.^{7}\right)$, tankers $\left(\mathrm{OCIMF}^{8}\right)$, and chemical tankers $\left(\mathrm{CDI}^{9}\right)$.

It is important to note that port state control (PSC) is not an obligation, but a right that allows port states to inspect a vessel calling a port under its jurisdiction. If a vessel is found to be non-compliant with the minimum requirements of the mandatory international legislative framework, it can be detained and deficiencies need to be rectified before the vessel can proceed. Detention is normally associated with high costs for ship owners, due to increased idle time in port and loss of business. There are currently ten port state control regimes which are grouped by regions operating worldwide.

In this article, the effect of safety inspections is evaluated in terms of reduced casualty risk. We consider port state control inspections of all ship types, and also industry vetting inspections performed on dry bulk carriers and tankers. We translate this reduction of incident risk into a monetary value, that is, the total estimated cost saving (TECS) due to an

\footnotetext{
${ }^{4}$ That is, tonnage of cargo shipped multiplied by the average distance transported.

${ }^{5}$ We use the term "incident" to cover accidents, casualties as defined by the International Maritime Organization (IMO), and total loss of a vessel, excluding constructive total loss for insurance purposes.

${ }^{6}$ Classification societies are technical bodies that originally designed vessels, but nowadays they have taken over all aspects of ship operations, and in many cases they act on behalf of flag states.

${ }^{7}$ RightShip performs vetting inspections on all ship types but primarily on dry bulk carriers and is located in Houston, London and Melbourne.

${ }^{8}$ Oil Companies International Marine Forum.

${ }^{9}$ Chemical Distribution Institute.
} 
inspection. In principle, the estimated risk probabilities may also be of interest for the insurance market (P\&I Clubs ${ }^{10}$ and marine underwriters).

The effectiveness of port state control or industry inspections has been treated in the literature from various angles, by Knapp and Franses [5], [6], [7], Carriou et al. [8], and Payoyo [9]. Most emphasis has so far been put on risk reduction in the sense of decreasing the probability of detention or casualty due to an inspection. Our aim in this paper is to quantify the decrease in costs associated with casualties.

The paper has the following structure. Section 2 describes the dataset and explains the various components used for the calculation of the base values to determine incident costs savings. Section 3 contains econometric models to estimate the effect of inspections. Section 4 presents the estimated incident cost savings due to port state control inspections, and Section 5 concludes.

\section{Dataset and determination of base values for incident costs}

The empirical analysis is based on data on an individual ship level of arrivals and port state control inspections and is complemented by information that is required to determine estimated cost savings of incidents. Notwithstanding the political aspects of port state control data on an individual ship level, we obtained the generous cooperation of the United States Coast Guard (USCG) and the Australian Maritime Safety Authority (AMSA). The dataset contains 515,194 ship arrivals of 15,819 ships for the time period from 2002 to 2007 . We use also vetting inspection information from RightShip for dry bulk carriers and vetting inspections from OCIMF and CDI for oil and chemical tankers.

The arrival and inspection dataset is merged with casualty data of the same time period (including relevant casualties from 2008), mainly originating from Lloyd's Register Fairplay. The dataset is further complemented by earnings, which represent ship economic cycles, obtained from the Shipping Intelligence Network of Clarksons. The combination of these various data sources allows us to estimate the probability of a ship having a casualty.

Our aim is to translate the effect of a port state control inspection into a monetary value. This value represents the total estimated cost savings (abbreviated henceforth by TECS) owing to the reduction of incident risk caused by a port state control inspection. These savings are calculated on an individual ship level and depend on the average costs of casualties. These costs are also denoted as "base values". The literature on costs of incidents provides an idea of the complexity of determining a realistic base value for incident costs. Wood [10] identifies four components to the costs of marine incidents, that is, lost assets, loss of cargo, lost lives, and pollution. It is very complex to estimate each of these components. Talley [11] investigates vessel damage cost differentials for some ship types and determinants of property damage costs of tanker accidents [12], and Goulielmos and Giziakis [13] consider uncompensated costs of marine accidents. For loss of life, various figures found in the literature are summarized by Skjong [14]. The values vary considerably, depending on the region. The International Maritime Organization (IMO) uses a value of USD 1.5 million in its guidelines for Formal Safety Assessment (FSA) [15]. In addition to the cost of lost lives, the costs of injuries are also important. The European Union Project SAFEDOR [16] suggests a range of USD 20,000 to 70,000 per injury, while the IMO FSA methodology

\footnotetext{
${ }^{10}$ Protection and Indemnity Clubs provide third party liability insurance in the shipping industry and are comprised of ship owners. Marine underwriters primarily insure hull and machinery.
} 
suggests a value of USD 42,000 per injury. As concerns the cost of pollution, there is currently no consensus at IMO level, but SAFEDOR provides an average figure of USD 60,000 [16] per ton. This figure does not take into account the associated costs of environmental damage (such as loss of animal life) and of other socio-economic factors, see Grigalunas et al [17] and Grey [18], since it is very difficult to estimate these costs.

In the rest of this section, we consider three alternative base values to calculate TECS, that is, historical claims figures, insurance premiums, and the total insured value.

In principle, historical claim figures are available from P\&I Clubs and Marine Underwriters. The P\&I Club figures cover all third party liability (general average, pollution, personnel, third party property damages) but exclude claims of cargo interest. The underwriter figures represent claims with respect to hull and machinery. Both values, however, will only reflect claims above the ship owner's deductible ${ }^{11}$, which can vary depending on the ship owner performance. In addition, the claim figures already reflect the effect of port state control and other inspections since they are historical figures influenced by safety inspections that reduce risk. The claim figures are therefore discounted. Average values are obtained from Knapp [19] and from P\&I Clubs and Marine Underwriters [20].

The insurance premium reflects the ship owners' portion of the value at risk as perceived by the insurance market. It excludes so-called cargo interests. Cargo interest premiums are very difficult to obtain since they are determined in a highly competitive global market and information on premiums is commercially sensitive. Third party liability will, however, cover ship owners' liabilities for third party claims for cargo. Similar to the claims, the premium only reflects coverage above the deductible, which can vary considerably because of individual judgment and agreed underwriting guidelines of cargo underwriters. We have identified premiums per ship type from Drewry Shipping Consultants [21] based on the International Group of P\&I Clubs ${ }^{12}$, adding $20 \%$ for administrative costs [21].

The most comprehensive base value to estimate cost savings of incidents is the total insured value (abbreviated henceforth by TIV). This value is influenced by the liability environment embedded in the legislative framework of the shipping industry. The components of TIV are the same as the ones identified by Wood [10] for the total costs of maritime incidents. This determines the value that can be recovered by insurance or stated otherwise, the value that can be insured. Based on insurance cover, the components of TIV are the following: (1) cost of hull and machinery (insured by Marine underwriters), (2) third party liability coverage (insured by P\&I Clubs), (3) oil pollution coverage for oil tankers (above the insurance limits from P\&I Clubs), and (4) cargo values for cargo carrying vessels (for passenger vessels, this is replaced by liability limits for injury or death of passengers).

First we consider the costs of hull and machinery. These values are insured on a valued policy basis according to the United Kingdom Marine Insurance Act of 1906. This means that the insured value is agreed between the underwriter and the owner and the underwriter will use his expert knowledge and other tools such as the Shipping Intelligence Network of Clarkson's [22] to assess the value. In addition, most vessels are mortgaged, which means that the insurance policy is assigned to the bank financing the vessel. The bank's primary concern is to ensure that the insured value is sufficient to cover the mortgage on the vessel in event of a total loss. The loan agreement will therefore stipulate the minimum value that is

\footnotetext{
${ }^{11}$ The deductible is the ship owner's portion of the claim; according to Knapp [19], based on industry sources, the deductible can vary from USD 50,000 to 250,000 for hull and machinery, from USD 5,000 to 30,000 for personnel related claims, and from USD 10,000 to 100,000 for all other claims.

${ }^{12}$ The International Group of P\&I clubs covers about $90 \%$ of the world fleet by gross tonnage, see Drewry [21].
} 
acceptable to the bank. These values can fluctuate according to the market situation. For the purpose of this article, we use the second hand prices of vessels $\left(\$ / D W T^{13}\right)$ from the Shipping Intelligence Network of Clarkson's [22], which provides monthly time series and which are adjusted for inflation ${ }^{14}$. The second hand prices are used since these prices provide the most realistic value of the asset.

Next, we consider third party liability coverage. This value is specified as being USD 10 million per incident [21], which in our case represents the maximum lower pooled amount for an individual P\&I Club (the split up is USD 8 million plus an allocated amount for the owner's deductible and a portion of excess loss reinsurance). According to industry sources, the trend is upwards from USD 8 million to USD 10 million. According to the International Group of P\&I Clubs, for oil tankers and for the period 1978-2002, 98\% of the cases are within the current limit of USD 8 million [23]. We will therefore take the USD 10 million limit including an allocation for the self-insured amount as our basis for the analysis.

Third, we consider oil pollution limits. These limits are based on the 1992 Civil Liability Convention and the 1992 Fund Convention and Supplementary Fund Protocol [24]. These limits for oil tankers are in excess to the third party liability used for the P\&I Clubs. The limits are presented in Table 1. The oil pollution limits are expressed in terms of so-called special drawing rights (SDR's) and conversion rates are defined by the International Monetary Fund (IMF). For the conversion of SDR's into USD, we used daily conversion rates $^{15}$ from January 2000 to December 2007. For other ship types than oil tankers, IMO adopted the International Convention on Civil Liability for Bunker Oil Pollution in March 2001, which has come into force in November 2008. This aspect is not taken into account in our analysis, as our data period runs until the end of 2007.

Table 1: Oil pollution limits for oil tankers

\begin{tabular}{|l|l|l|}
\hline Ship size (in gt) & Till Oct 31, 2003 & From Nov 1, 2003 \\
\hline up to 5000 & $\begin{array}{l}3,000,000 \text { SDR } \\
\text { (USD 4.6 million) }\end{array}$ & $\begin{array}{l}4,510,000 \text { SDR } \\
\text { (USD 6.9 million) }\end{array}$ \\
5000 to 140,000 & $\begin{array}{l}3,000,000 \text { SDR plus 420 SDR } \\
\text { for each additional tonnage } \\
\text { (USD 4.6 million plus USD 647) }\end{array}$ & $\begin{array}{l}\text { 4,510,000 SDR plus 631 SDR for each } \\
\text { (Udditional tonnage } \\
\text { (USD 6.9 million plus USD 972) }\end{array}$ \\
140,000 and above & $\begin{array}{l}\text { 59,700,000 SDR } \\
\text { (USD 92 million) }\end{array}$ & $\begin{array}{l}\text { 89,770,000 SDR } \\
\text { (USD 138.3 million) }\end{array}$ \\
\hline
\end{tabular}

Note: The amounts in USD are approximate values as of December 2008.

Finally, the fourth component of TIV is the value of cargo that is carried by ships each year. We use data from the United Nations Commodity Trade Statistics database [25], together with an estimated share of seaborne cargo varying from $64 \%$ in 2000 to $70 \%$ in 2007 . The relevant value is calculated for each year. The total seaborne values are compared with values from the UNCTAD Maritime Transport Review [26], which represent cargo value of imports (c.i.f.), and to values given by Hoffman [27] based on data from GlobalInsight. We use the average of the three values as the base to determine average cargo values per cargo carrying capacity (DWT) per day. The resulting cargo values are presented in Table 2 . As an estimate of total days at risk, we use an average of 224 days at sea, based on data used in the IMO 2009 Greenhouse Gas study [28]. It is worth noting that these values do not reflect the

\footnotetext{
${ }^{13}$ DWT denotes the deadweight, that is, the cargo carrying capacity of a ship.

${ }^{14}$ Historical monthly inflation rates are obtained from http://www.inflationdata.com

${ }^{15}$ Daily conversion rates are obtained from the home page of the IMF, http://www.imf.org/external/index.htm
} 
different cargo values per ship type, which can vary considerably. For instance, container vessels can carry high value cargo as compared to general cargo vessels.

Table 2: Estimated cargo values per year and DWT

\begin{tabular}{|c|cccc|c|c|}
\hline \multirow{2}{*}{ Year } & \multicolumn{3}{|c|}{ Total seaborne cargo value (billion USD) } & Total DWT (million) & Cargo value \\
\cline { 2 - 5 } & UN-Data & UNCTAD & GlobalInsight & Average & cargo carrying fleet & (DWT/day) \\
\hline 2000 & 2,762 & 6,642 & 4696 & 4,700 & 800.3 & 18.73 \\
2001 & 2,489 & 5,960 & 4452 & 4,300 & 821.9 & 16.69 \\
2002 & 2,643 & 6,205 & 4528 & 4,459 & 835.3 & 17.19 \\
2003 & 3,485 & 7,685 & 5165 & 5,445 & 854.3 & 21.14 \\
2004 & 4,479 & 9,447 & 6460 & 6,795 & 878.4 & 26.14 \\
2005 & 5,215 & 10,712 & 7463 & 7,797 & 927.1 & 28.73 \\
2006 & 5,881 & 11,978 & 8503 & 8,787 & 989.8 & 30.42 \\
2007 & 6,546 & 13,243 & 9543 & 9,777 & 1058.1 & 31.74 \\
\hline
\end{tabular}

For passenger vessels, the concept of insured cargo limits does not apply. Therefore, we consider liability limits with respect to the carriage of passengers at sea. The respective IMO convention is the Athens Convention relating to the carriage of passengers and their luggage by sea, which was adopted in 1974 and which has been revised several times. The Athens Convention uses SDR's like the CLC Convention, and the current limit is SDR 46,666 (approximately USD 61,000) [29] per carriage for death or personal injury. The 2002 Protocol of 1974 convention raised the limits to SDR 175,000 (USD 224,000) but this protocol is not yet in force. For the purpose of our analysis, we use the current limit and convert SDR into USD using the daily conversion rates from the International Maritime Fund.

The three base values are calculated on an individual ship level. Mean and median (for TIV) values for the employed dataset are presented in Table 3. These values have been adjusted for inflation $^{16}$. For the calculation of TEC, we will use the TIV value as base value.

Table 3: Comparison of three average base values per ship type (2000 to 2007, in USD)

\begin{tabular}{|l|r|r|r|r|}
\hline & \multicolumn{2}{|c|}{ Total insured value (TIV) } & $\begin{array}{r}\text { Premium } \\
\text { (excl. cargo) }\end{array}$ & $\begin{array}{r}\text { Historical } \\
\text { claims }\end{array}$ \\
\hline Ship type & Mean & Median & Mean & Mean \\
\hline General cargo & $32,621,361$ & $26,740,979$ & 216,570 & 92,478 \\
Dry bulk & $48,454,593$ & $35,239,899$ & 348,941 & 119,583 \\
Container & $40,457,674$ & $36,951,880$ & 404,317 & 130,711 \\
Tanker & $81,610,817$ & $66,530,046$ & 511,965 & 223,200 \\
Passenger & $152,232,961$ & $166,277,942$ & $1,949,086$ & 339,328 \\
Other ship types & $13,077,190$ & $11,047,671$ & 213,736 & 140,701 \\
\hline Average & $57,842,735$ & $40,684,226$ & 607,436 & 174,334 \\
\hline
\end{tabular}

Note: The mean and median values apply to the set of ships that is present in the dataset employed in this paper.

\section{Econometric models and estimation results}

We use a combination of duration analysis and binary logistic regression on individual ship data to estimate hazard rates, the probability of survival, the probability of having a casualty, and the effect of inspections on these probabilities. Our so-called "Type A models" are the main models of our analysis and measure the effect of an inspection based on duration analysis. For each ship type, we estimate the hazard models and we translate the results into

${ }^{16}$ Historical monthly inflation rates are obtained from http://www.inflationdata.com 
survival gains. The obtained survival gains are combined with the total insured value (TIV) to determine the total estimated cost savings (TECS) due to an inspection. The outcomes can be interpreted as an upper bound for the actual gains, because (total loss) shipping accidents do not always involve a $100 \%$ loss of all value as measured by TIV. Our so-called "Type B models" are secondary in importance and estimate the probabilities of incurring the loss of each of the four components that make up TIV. We use these probabilities as correction factors to obtain a lower bound for TECS. The type B models are briefly explained in Appendix 2.

The type A models use duration analysis (also called survival analysis) to measure the risk of a total loss in terms of a set of risk factors. The object of central interest in duration analysis is the so-called hazard rate, which is the instantaneous incident rate at a given age of a ship given survival up to that age. Once the hazard rate is known, one can calculate the probability of survival of a vessel, since there is a direct relationship between the hazard rate and the survival probability. To be more precise, let $S(t)$ be the survival function, that is, the probability that the ship will survive for at least $t$ periods from its creation. Then the hazard rate, denoted by $\lambda(t)$, is defined by $\lambda(t)=-\mathrm{d} \ln (S(t)) / \mathrm{d} t .^{17}$ We refer to Van den Berg [30] for further explanation of hazard rates and duration models.

A large hazard rate corresponds to a large risk that the ship will not survive for long. The model is defined in terms of a baseline hazard function $\lambda_{b}(t)$ for the effect of the age of a ship and a multiplicative effect of include covariates. The baseline hazard is chosen to be piecewise constant. There are six age groups, and $\lambda_{b}(t)=\exp \left(\beta_{0}\right)$ in the youngest age group (taken as reference category) and $\lambda_{b}(t)=\exp \left(\beta_{0}+\alpha_{j}\right)$ in age group $j$, for $j=2, \ldots, 6$. The model contains, apart from age, also $k$ other risk factors that are denoted by $\left(X_{l}, \ldots, X_{k}\right)$, and the hazard rate is specified as

$$
\lambda(t)=\lambda_{b}(t) \exp \left(\beta_{1} X_{1}(t)+\ldots+\beta_{k} X_{k}(t)\right)=\lambda_{b}(t) \exp \left(\beta_{1} X_{1}(t)\right) \ldots \exp \left(\beta_{k} X_{k}(t)\right)
$$

This is called a proportional hazard model, as each risk factor has a proportional effect on the hazard rate. The type A models are estimated using total loss casualties as life-ending incidents, where "total loss" is defined in terms of the classification of casualties used by the IMO, according to MSC/Circ. 953, MEPC/Circ. 372 [31], and MSC Resolution MSC.255(84) [32]. The models are specified using a similar methodology as in Bijwaard and Knapp [3], but with a reduced number of variables. The risk affecting factors are summarized in Table 4 and include, next to current arrival inspection indicators, also past incidents, past inspections, economic conditions, and several ship particulars, including size of the vessel, flag, flag changes, classification society, and Document of Compliance (DoC) Company. ${ }^{18}$ Another important factor affecting ship safety consists of ship economic cycles, represented by average monthly earnings. This variable is based on data from Clarkson's Shipping Intelligence Network, deflated using average inflation percentages for the US for the time period at hand.

Further, in order to get a manageable number of variables indicating registration of a vessel, the flags are grouped according to a classification used by the Paris Memorandum of Understanding (MoU). The classification is "black", "grey" and "white". Classification

\footnotetext{
${ }^{17}$ Here, 'ln' denotes the natural logarithm, and the survival function is obtained by $S(t)=\exp \left(-\int_{0}^{t} \lambda(s) d s\right)$.

${ }^{18}$ Whereas classification societies are technical organizations that are responsible for the construction and maintenance of ships, DoC Companies are designated companies responsible for the safety management.
} 
societies are grouped according to their association with the International Association of Classification Societies (IACS). IACS is an important club of societies that guarantee a certain level of quality. For the classification of the DoC Company, we group the countries of location of the Company into the five categories used by UNCTAD (OECD countries, former Eastern European Countries, developing countries, least developed countries, and a rest category for unknown country of location).

Table 4: Variables used in the hazard models

\begin{tabular}{|c|c|c|}
\hline Variable & $\begin{array}{c}\begin{array}{c}\text { Number of } \\
\text { values }\end{array} \\
\end{array}$ & $\begin{array}{l}\text { Duration interval } \\
\text { (related to arrival) }\end{array}$ \\
\hline \multicolumn{3}{|l|}{ Current arrival } \\
\hline Port state control inspection & 1 & 360 days after \\
\hline Industry vetting inspection (RightShip) - dry bulk & 1 & 360 days after \\
\hline Industry vetting inspection (CDI,OCIMF) - tanker & 1 & 360 days after \\
\hline \multicolumn{3}{|l|}{ Ship particulars } \\
\hline Tonnage (logarithm) & 1 & $\mathrm{n} / \mathrm{a}$ \\
\hline Past port state control detention & 1 & 360 days before \\
\hline Past total port state control deficiencies & 1 & 360 days before \\
\hline Flag state Group & 4 & $\mathrm{n} / \mathrm{a}$ \\
\hline Change of flag & 1 & 360 days before \\
\hline Change of DoC company & 1 & 360 days before \\
\hline Classification society group & 3 & $\mathrm{n} / \mathrm{a}$ \\
\hline DoC company country of location & 5 & $\mathrm{n} / \mathrm{a}$ \\
\hline \multicolumn{3}{|l|}{ Ship accident history } \\
\hline Less serious casualties & 2 & 180 and 360 days before \\
\hline Serious casualties & 2 & 180 and 360 days before \\
\hline Very serious casualties & 2 & 180 and 360 days before \\
\hline \multicolumn{3}{|l|}{ Economic conditions } \\
\hline Average earnings per day & 1 & $\mathrm{n} / \mathrm{a}$ \\
\hline
\end{tabular}

We estimate separate models for each ship type (general cargo, dry bulk carrier, container vessels, tankers, and passenger vessels) and for each year from 2003 to 2007, using an expanding estimation window that stretches up to the year of arrival. The results of the hazard models for each ship type are given in Appendix 1.A to 1.E. For all ship types, inspections decrease the incident risk of total loss, and this effect is significant at the $1 \%$ level in 30 out of 33 cases. The coefficient measuring the inspection effect is not significant in three cases, that is, in 2007 for port state control inspections of tankers, and in 2003 for port state control inspections of general cargo vessels and for RightShip inspections of dry bulk carriers. The latter result can be explained by to the fact that RightShip inspections only started around 2003.

We refer to Appendix 1.A-1.E for more detailed results, and we mention some results of interest. Previous very serious casualties increase the hazard for general cargo vessels and tankers, but this is not the case for the other three ship types. The hazard is larger for black listed flags for general cargo vessels, dry bulk carriers, tankers and passenger vessels, and this effect does not seem to change over time. As concerns classification societies, IACS classification societies do not perform any better than NIACS for all ship types. DoC companies from unknown locations perform worst for all ship types. Ship economic cycles present a somewhat mixed picture, but on when significant, a higher level of activity is commonly related to higher hazard rates.

The results of the hazard models in Appendix 1.A-1.E can be used to evaluate the benefits of inspections in terms of reduced casualty risk, which we denote as survival gains. Consider a 
ship that at the current time $(t)$ is in port, that belongs to age group $j$ and that has values $\left(X_{1}\right.$, $\ldots, X_{k}$ ) for the explanatory variables. Let $X_{l}$ be the variable that reflects the decision whether or not a ship is inspected, with $X_{1}=0$ if this ship is not inspected and $X_{1}=1$ if it is inspected. The corresponding hazard rates are (ceteris paribus) $\lambda_{0}=\exp \left(\beta_{0}+\alpha_{j}+\beta_{2} X_{2}+\ldots+\beta_{k} X_{k}\right)$ if the ship is not inspected, and $\lambda_{1}=\lambda_{0} \exp \left(\beta_{l}\right)$ if it is inspected. As $\beta_{l}<0$ in our models, this means that $\exp \left(\beta_{1}\right)<1$, so that an inspection reduces the hazard rate and hence the risk of a total loss accident. Let $S_{0}$ and $S_{1}$ denote the corresponding probabilities of survival for the coming year (from $t$ till $t+1$ ), then the gained chance of survival due to inspecting this ship is

$$
S_{1}-S_{0}=\exp \left(-\int_{t}^{t+1} \lambda_{1}(s) d s\right)-\exp \left(-\int_{t}^{t+1} \lambda_{0}(s) d s\right)
$$

This formula gives the inspection gains (SG) for port state control inspections and for industry inspections. The average gains per ship type and per year are shown in Table 5. The survival gains range roughly from $0.1 \%$ to $0.5 \%$, which is not negligible for risk rates of roughly $1 \%$ to $3 \%$. In the next section, this reduction in risk is combined with the involved values at risk, which will show considerable monetary benefits of ship inspections.

Table 5: Average survival gains $\left(\mathrm{S}_{1}-\mathrm{S}_{0}\right)$ and probability of survival $\left(\mathrm{S}_{0}\right)$, per year and ship type

\begin{tabular}{|c|c|c|c|c|c|c|c|c|c|c|}
\hline & \multicolumn{2}{|c|}{2003} & \multicolumn{2}{|c|}{2004} & \multicolumn{2}{|c|}{2005} & \multicolumn{2}{|c|}{2006} & \multicolumn{2}{|c|}{2007} \\
\hline & $S_{1}-S_{0}$ & $S_{0}$ & $S_{1}-S_{0}$ & $S_{0}$ & $S_{1}-S_{0}$ & $S_{0}$ & $S_{1}-S_{0}$ & $\mathrm{~S}_{0}$ & $S_{1}-S_{0}$ & $S_{0}$ \\
\hline \multicolumn{11}{|c|}{ Port State Control } \\
\hline General cargo & 0.0012 & 0.9625 & 0.0026 & 0.9624 & 0.0042 & 0.9639 & 0.0043 & 0.9622 & 0.0044 & 0.9607 \\
\hline Container & 0.0041 & 0.9808 & 0.0017 & 0.9865 & 0.0023 & 0.9858 & 0.0016 & 0.9857 & 0.0017 & 0.9852 \\
\hline Tanker & 0.0020 & 0.9782 & 0.0025 & 0.9761 & 0.0031 & 0.9756 & 0.0024 & 0.9738 & 0.0009 & 0.9731 \\
\hline Dry bulk & 0.0043 & 0.9754 & 0.0053 & 0.9712 & 0.0058 & 0.9707 & 0.0057 & 0.9673 & 0.0044 & 0.9684 \\
\hline Passenger & $\mathrm{n} / \mathrm{a}$ & $\mathrm{n} / \mathrm{a}$ & $\mathrm{n} / \mathrm{a}$ & $\mathrm{n} / \mathrm{a}$ & 0.0034 & 0.9849 & 0.0033 & 0.9837 & 0.0037 & 0.9830 \\
\hline \multicolumn{11}{|c|}{ Vetting inspections } \\
\hline Tanker & 0.0026 & 0.9794 & 0.0022 & 0.9778 & 0.0031 & 0.9777 & 0.0047 & 0.9749 & 0.0052 & 0.9725 \\
\hline Dry bulk & 0.0028 & 0.9774 & 0.0042 & 0.9731 & 0.0045 & 0.9730 & 0.0051 & 0.9694 & 0.0055 & 0.9702 \\
\hline
\end{tabular}

\section{Total estimated cost savings of reduced total loss risk due to inspections}

The total estimated cost savings (TECS) of total loss incidents due to inspections are calculated for each ship arrival in the dataset, by means of the following steps. First, we estimate the four components of the total insured value (TIV), described in Section 2. TIV represents the estimated total insured value for a life ending incident, that is, the maximal value at stake in case of a $100 \%$ total loss of all value involved in the ship, its crew and cargo, as well as external effects including pollution. Second, we determine the survival gain (SG), which is the reduction in risk due to an inspection and which is estimated by means of duration analysis, as described in Section 3. If SG is converted to a monetary value using the full value of TIV, this provides an upper bound for TECS.

Even if there is a total loss, not all components of TIV will be equally affected. This occurs, for example, if the ship is lost but there are survivors or if pollution is prevented. It is, however, difficult to find industry information about the historical spread of the losses across the components of TIV. As an approximation, and as a third step, given the situation of an accident, we estimate the probability of occurrence (denoted by $\mathrm{P}$ ) for each of the four components of TIV. These probabilities are obtained from, what we call, Type B models, 
using binary logistic regression, as explained in Appendix 2. These probabilities serve to reduce the four TIV value components to get a smaller and possibly more realistic value at risk exposure. As the probabilities are estimated using a wider range of accidents than total loss accidents alone, the risks involved in total loss accidents may well be higher than those obtained from the Type B models. For this reason, we consider the obtained values as providing a lower bound of TECS.

Equation (1) below determines an upper bound of TECS, obtained by multiplying SG by TIV. A lower bound is specified in Equation (2), where the four value components of TIV are denoted by $\mathrm{VAL}_{j}$ (with $\mathrm{j}=1, \ldots, 4$, with $\mathrm{j}=1$ for hull and machinery, $\mathrm{j}=2$ for loss of life, $\mathrm{j}=3$ for third party liability, and $\mathrm{j}=4$ for oil pollution). Each of these values is multiplied by its probability of occurrence that applies for the ship under consideration and that is denoted by $\mathrm{p}_{\mathrm{j}}$.

$$
\text { Upper bound: } \quad \text { TECS }=\mathrm{SG} \times \mathrm{TIV}
$$

$$
\text { Lower bound: } \quad \text { TECS }=\mathrm{SG} \times\left(\mathrm{p}_{1} \times \mathrm{VAL}_{1}+\mathrm{p}_{2} \times \mathrm{VAL}_{2}+\mathrm{p}_{3} \times \mathrm{VAL}_{3}+\mathrm{p}_{4} \times \mathrm{VAL}_{4}\right)
$$

The results for port state control inspections are given in Table 6, and those for industry inspections in Table 7. The tables show both mean and median values of the lower and upper bounds of TECS, grouped per ship type, age group, and size group. Appendix 3.A and 3.B contain more detailed results for port state control inspections, for each ship type and age group.

Table 6: TECS of port state control inspections (in thousands of USD)

\begin{tabular}{|l|r|r|r|r|}
\hline & \multicolumn{2}{|c|}{ Upper bound } & \multicolumn{2}{|c|}{ Lower bound } \\
\cline { 2 - 4 } & Mean & Median & Mean & Median \\
\hline Ship types & & & & \\
General cargo & 202.4 & 44.1 & 110.6 & 21.0 \\
Dry bulk & 158.7 & 36.3 & 87.0 & 18.6 \\
Container & 98.4 & 22.4 & 46.0 & 9.9 \\
Tanker & 201.4 & 61.3 & 71.7 & 21.3 \\
Passenger & 533.3 & 550.2 & 34.4 & 34.1 \\
\hline Age groups (year) & & & & \\
up to 5 & 129.7 & 34.7 & 34.0 & 14.2 \\
6 to 10 & 113.3 & 28.3 & 31.8 & 12.0 \\
11 to 15 & 108.5 & 34.4 & 30.6 & 14.7 \\
16 to 20 & 129.8 & 47.5 & 52.1 & 20.0 \\
21 to 25 & 470.9 & 164.3 & 219.2 & 74.7 \\
above 25 & 543.7 & 145.7 & 272.2 & 51.3 \\
\hline Size groups (gt) & & & & \\
below 10,000 & 41.9 & 16.5 & 16.6 & 6.2 \\
10,001 to 20,000 & 116.1 & 20.5 & 57.8 & 9.2 \\
20,001 to 30,000 & 163.4 & 41.0 & 79.8 & 16.1 \\
30,001 to 40,000 & 230.3 & 63.9 & 95.1 & 27.2 \\
40,001 to 50,000 & 191.9 & 56.6 & 77.4 & 22.6 \\
above 50,000 & 326.5 & 125.9 & 91.0 & 35.4 \\
\hline All ships & 192.8 & 45.9 & 74.0 & 18.9 \\
\hline Note: The reportedmy
\end{tabular}

Note: The reported mean and median values are based on all observations in the employed dataset.

When averaged over all ships, the average TECS for port state control inspections ranges from USD 74 to 192.8 thousand (median USD 18.9 to 45.9 thousand). For industry inspections on dry bulk carriers, this range is USD 93.5 to 169.5 thousand (median USD 16.8 
to 33.1 thousand). For industry inspections on tankers, this range is USD 136.7 to 379 thousand (median USD 43.6 to 131 thousand). It is not surprising that cost savings of industry inspections are the highest, especially for tankers, since industry inspections are much more extensive than port state control inspections. For dry bulk carriers, the cost savings due to industry inspections are lower than for tankers because of the lower TIV values that are involved, see Table 3.

Table 6 shows that based on the upper bound of the average TECS, general cargo ships have second highest cost saving after passenger vessels for port state control inspections. This ordering changes, however, when we base the cost savings on the lower bound of the average TECS. The median TECS indicates the highest cost savings for passenger vessels followed by tankers and general cargo vessels. In terms of the lower bound, the limited risk associated with loss of life leads to an enormous reduction of the average cost savings for passenger vessels.

Table 7: TECS of industry inspections (in thousands of USD)

\begin{tabular}{|c|c|c|c|c|}
\hline & \multicolumn{2}{|c|}{ Upper bound } & \multicolumn{2}{|c|}{ Lower bound } \\
\hline & Mean & Median & Mean & Median \\
\hline $\begin{array}{l}\text { Dry bulk carriers: age groups (year) } \\
\text { up to } 5\end{array}$ & 99.9 & 18.1 & 53.4 & 9.3 \\
\hline 6 to 10 & 83.6 & 16.7 & 44.1 & 8.6 \\
\hline 11 to 15 & 106.0 & 33.3 & 57.9 & 17.5 \\
\hline 16 to 20 & 127.7 & 31.4 & 68.3 & 15.6 \\
\hline 21 to 25 & 559.5 & 153.5 & 310.8 & 78.6 \\
\hline above 25 & 518.3 & 161.4 & 306.8 & 95.0 \\
\hline Dry bulk carriers: size groups (gt) & & & & \\
\hline below 10,000 & 73.3 & 72.0 & 30.3 & 28.9 \\
\hline 10,001 to 20,000 & 56.6 & 9.3 & 29.3 & 4.5 \\
\hline 20,001 to 30,000 & 139.8 & 20.0 & 83.1 & 10.0 \\
\hline 30,001 to 40,000 & 110.7 & 33.5 & 60.0 & 17.1 \\
\hline 40,001 to 50,000 & 120.6 & 35.9 & 64.3 & 19.2 \\
\hline above 50,000 & 360.3 & 100.4 & 197.6 & 53.7 \\
\hline Dry bulk carriers: all & 169.5 & 33.1 & 93.5 & 16.8 \\
\hline Tankers; age groups (year) & & & & \\
\hline up to 5 & 242.0 & 110.6 & 85.4 & 36.8 \\
\hline 6 to 10 & 297.2 & 124.3 & 108.7 & 40.9 \\
\hline 11 to 15 & 303.9 & 127.1 & 113.7 & 44.1 \\
\hline 16 to 20 & 201.7 & 87.4 & 72.4 & 27.9 \\
\hline 21 to 25 & 1023.6 & 430.1 & 375.6 & 155.4 \\
\hline above 25 & 2812.2 & 749.6 & 981.5 & 260.9 \\
\hline Tankers: size groups $(g t)$ & & & & \\
\hline below 10,000 & 66.1 & 20.4 & 20.5 & 6.0 \\
\hline 10,001 to 20,000 & 183.9 & 57.0 & 61.6 & 18.3 \\
\hline 20,001 to 30,000 & 196.0 & 82.8 & 69.0 & 27.4 \\
\hline 30,001 to 40,000 & 657.0 & 294.7 & 245.5 & 103.8 \\
\hline 40,001 to 50,000 & 315.6 & 163.3 & 114.1 & 55.7 \\
\hline above 50,000 & 482.1 & 217.5 & 170.1 & 77.4 \\
\hline Tankers: all & 379.0 & 131.0 & 136.7 & 43.6 \\
\hline
\end{tabular}

Note: The reported mean and median values are based on all observations in the employed dataset.

Figure 1 and 2 visualize the upper and lower bounds for port state control inspections, per age group and per size (gross tonnage) group. This shows clearly that the gap between the upper and lower bounds is more pronounced for age than for size. The results based on age groups in Figure 1 demonstrate that older ships, especially in the older age brackets show 
higher cost savings for port state control inspections. From the results for size groups in Figure 2, one can observe that the size group from 30 to 40 thousand gt and that above 50 thousand gt present the highest TECS. Similar results hold true for industry inspections of tankers and dry bulk carriers, as we will see below (see Figures 4 and 5). Figure 3 provides a differentiation between the five ship types and visualizes differences per ship type and age group. This figure shows that cost savings increase per age group for all ship types, with the exception of passenger vessels.

Figure 1: Median TECS per age group - port state control inspections, all ships

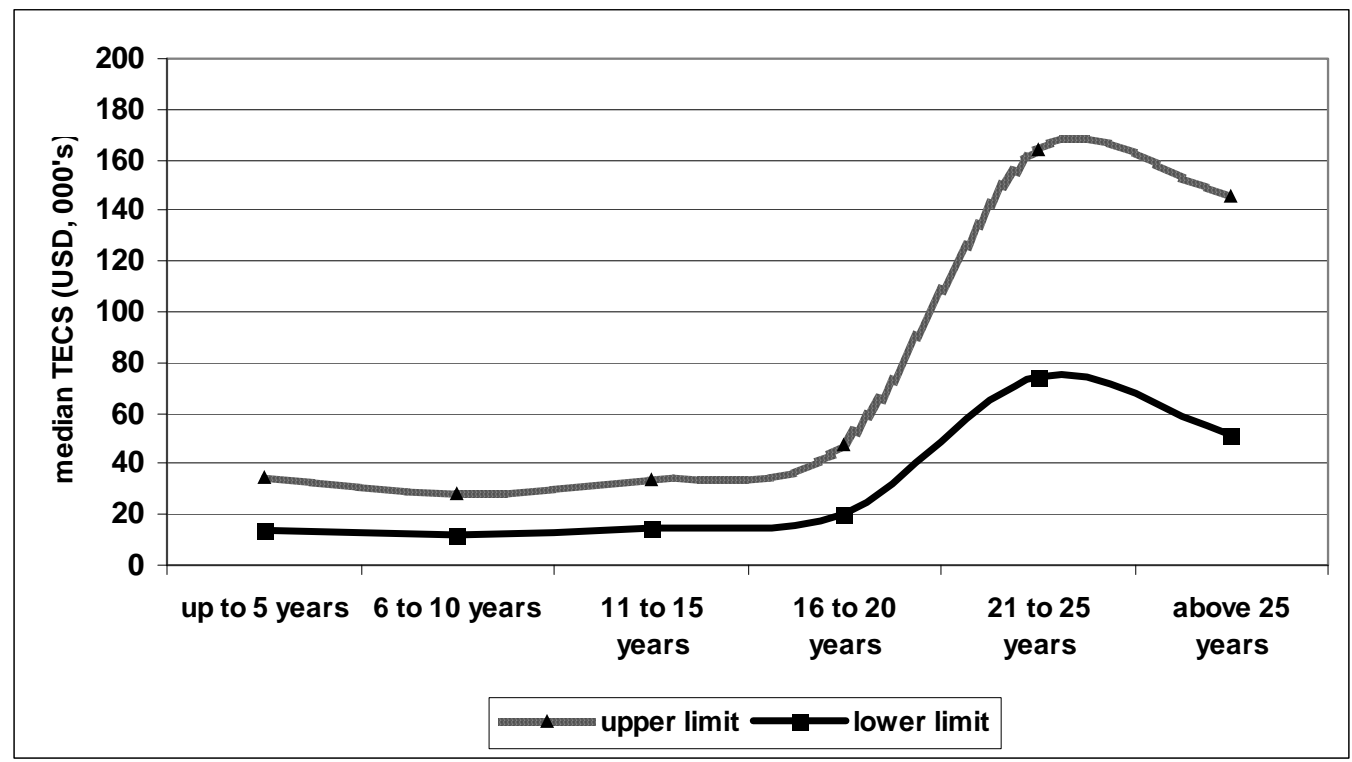

Figure 2: Median TECS per size group - port state control inspections, all ships

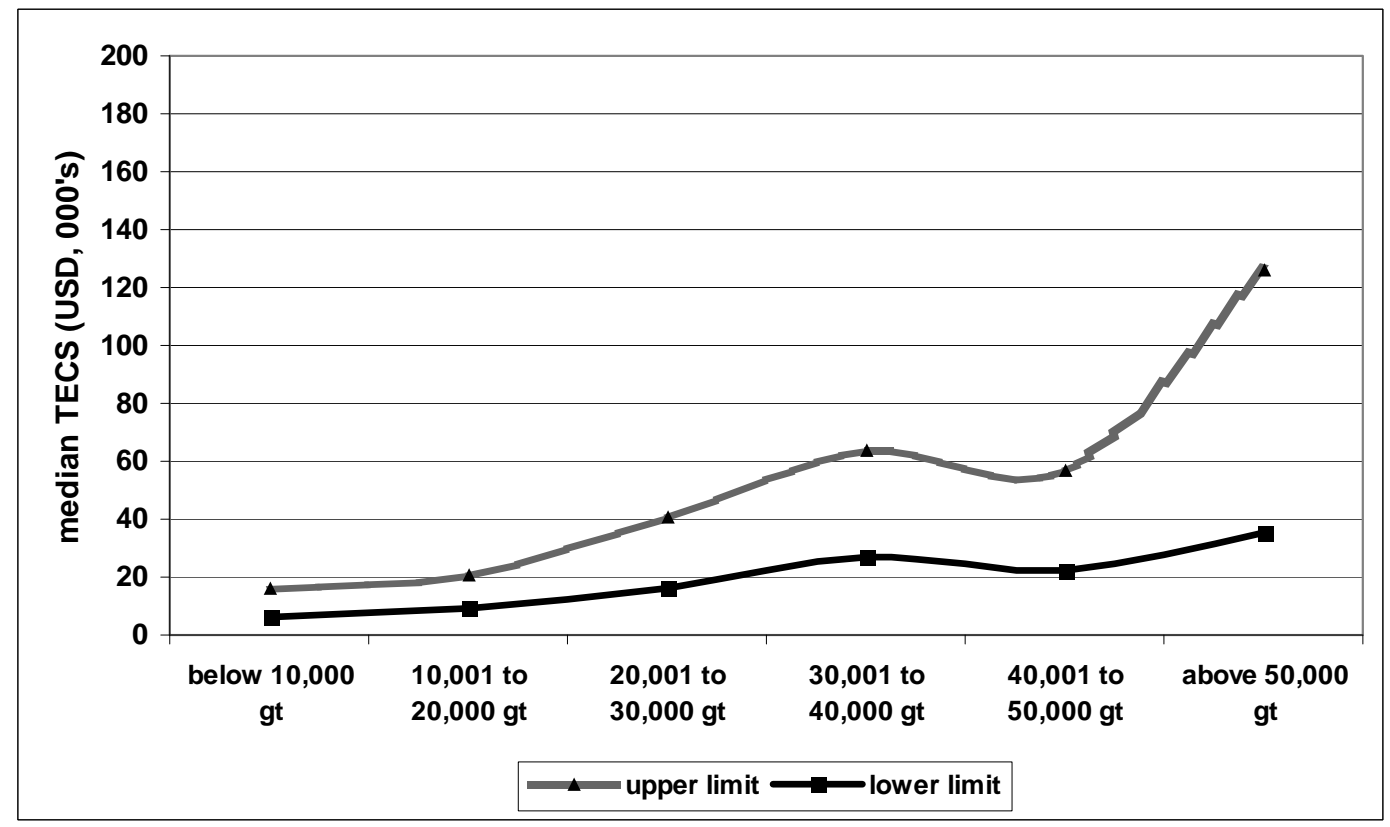

Figure 4 and 5 present the median upper and lower bounds of TECS for the vetting inspections for dry bulk carriers and tankers per age group and size group. As expected, cost savings for dry bulk carriers are lower than for tankers, since the TIV for tankers is higher 
Figure 3: Median TECS upper bound per age group and ship type - port state control

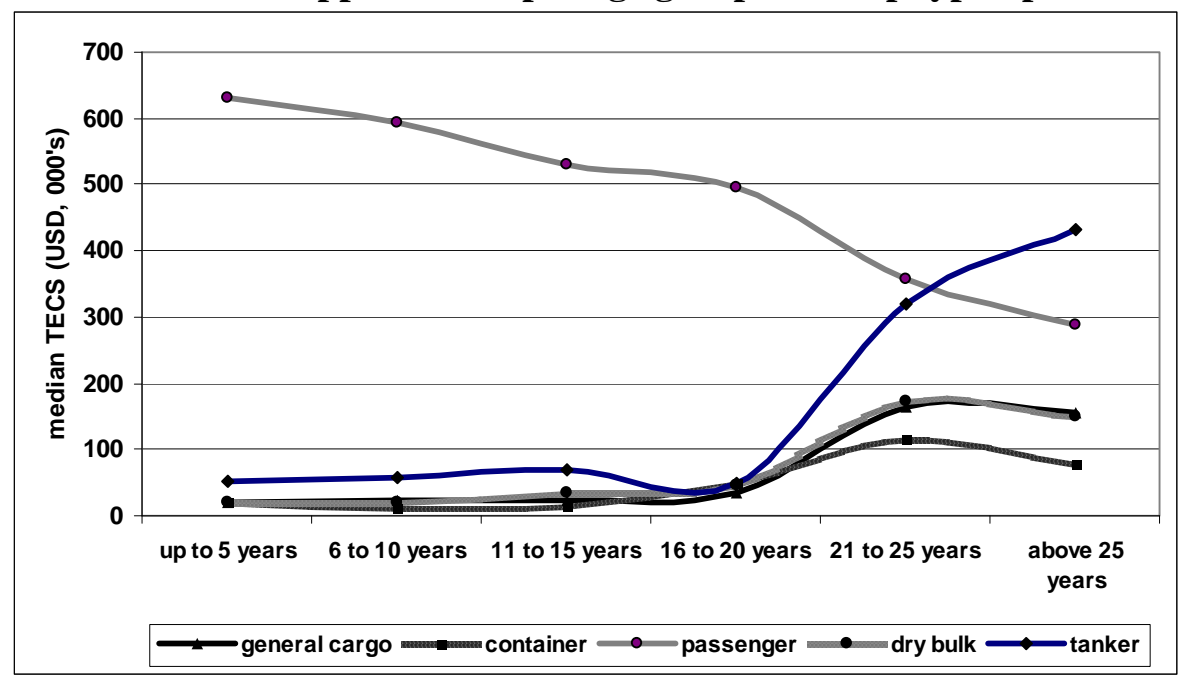

Figure 4: Median TECS per age group - industry inspections, tankers and dry bulk

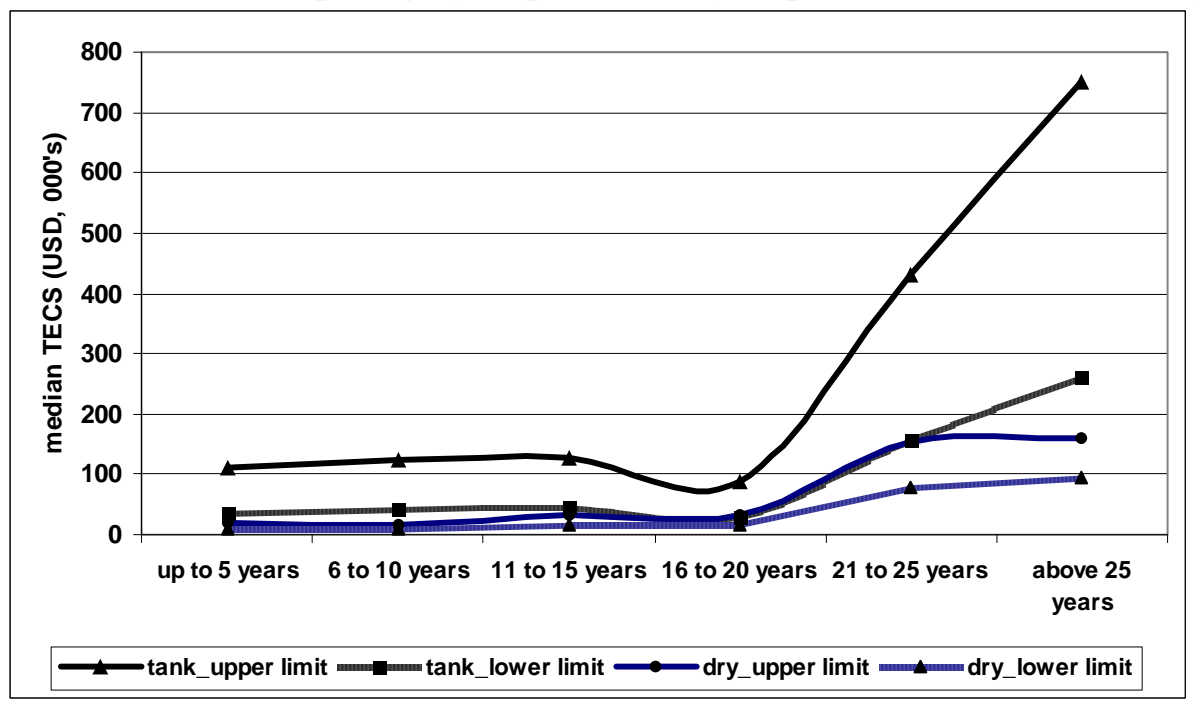

Figure 5: Median TECS per size group - industry inspections, tankers and dry bulk

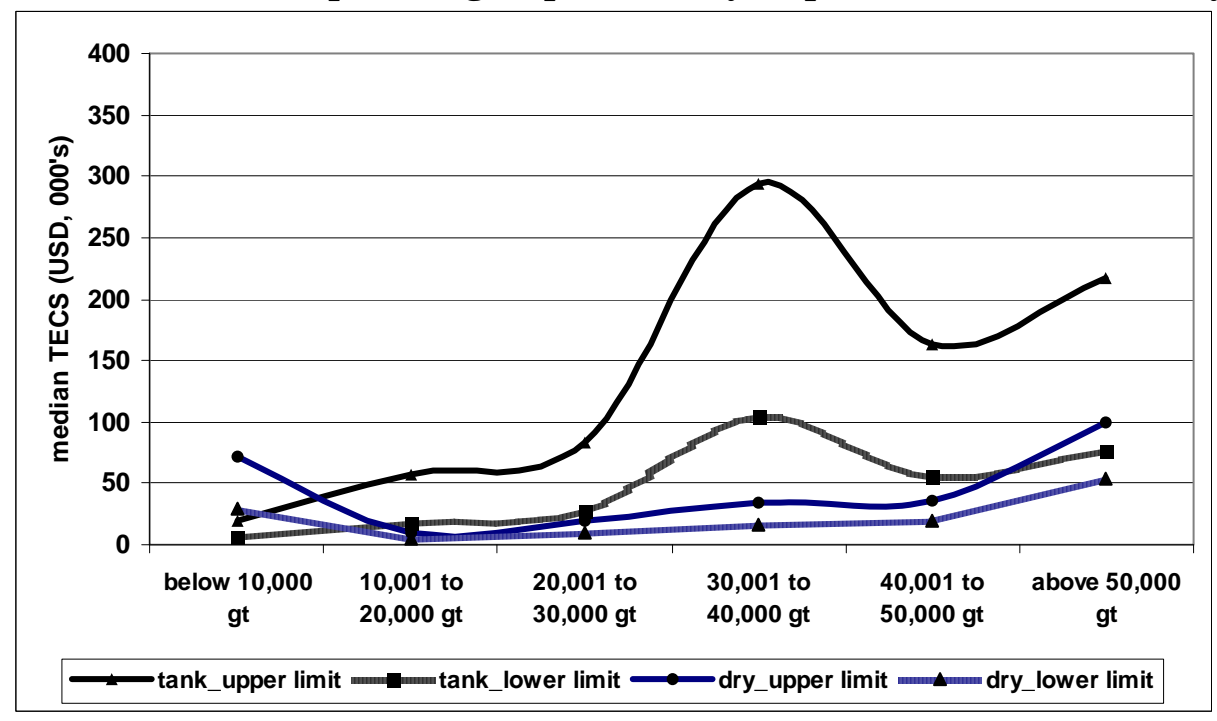


due to the limits for oil pollution, see also Table 3. For tankers, the cost savings from vetting inspections surpass those of port state control inspections by a considerable margin.

Table 8 presents TECS results for all inspection types, differentiated by flag group and classification society group and averaged over all five ship types. The largest TECS are obtained for ships with undefined flag and unknown classification society. Note, however, that ships with white listed flag or IACS class do not always present the lowest value.

Table 8: TECS per flag and classification society group (in thousands of USD)

\begin{tabular}{|c|c|c|c|c|}
\hline & \multicolumn{2}{|c|}{ Upper bound } & \multicolumn{2}{|c|}{ Lower bound } \\
\hline & Mean & Median & Mean & Median \\
\hline Port state control inspections, all ships & & & & \\
\hline Black listed flag & 180.4 & 38.3 & 77.6 & 16.4 \\
\hline Grey listed flag & 157.1 & 41.8 & 65.0 & 15.5 \\
\hline Undefined flag & 477.7 & 95.2 & 311.4 & 52.0 \\
\hline White listed flag & 191.3 & 51.6 & 63.6 & 20.1 \\
\hline IACS class & 188.9 & 45.4 & 74.9 & 18.7 \\
\hline Non-IACS class & 218.8 & 48.8 & 67.9 & 20.3 \\
\hline Unknown class & $1,201.1$ & 377.0 & 581.4 & 157.1 \\
\hline Industry inspections - dry bulk & & & & \\
\hline Black listed flag & 163.8 & 29.1 & 89.2 & 14.9 \\
\hline Grey listed flag & 205.4 & 34.7 & 102.3 & 16.8 \\
\hline Undefined flag & 510.1 & 150.2 & 329.1 & 98.7 \\
\hline White listed flag & 124.5 & 27.9 & 67.6 & 14.4 \\
\hline IACS class & 167.0 & 33.1 & 92.4 & 16.9 \\
\hline Non-IACS class & 225.3 & 31.1 & 116.3 & 14.0 \\
\hline Unknown class & 819.3 & 601.8 & 449.1 & 328.6 \\
\hline Industry inspections - tankers & & & & \\
\hline Black listed flag & 295.6 & 84.7 & 108.4 & 28.3 \\
\hline Grey listed flag & 243.7 & 95.6 & 73.0 & 26.8 \\
\hline Undefined flag & 334.4 & 130.8 & 139.3 & 53.8 \\
\hline White listed flag & 416.0 & 150.1 & 150.9 & 51.5 \\
\hline IACS class & 378.8 & 128.6 & 137.2 & 42.9 \\
\hline Non-IACS class & 379.7 & 143.3 & 133.3 & 48.0 \\
\hline Unknown class & $1,543.7$ & $1,077.0$ & 659.0 & 501.1 \\
\hline
\end{tabular}

Note: The reported mean and median values are based on all observations in the employed dataset.

We finally consider the costs associated with port state control and other inspections. These costs vary per country and by type of inspection, and average selected values are presented in Table 9. Here we consider shore side and shipboard inspection costs, based on Knapp and Franses [4] and on information obtained directly from the Australian Maritime Safety Authority (AMSA) and the United States Coast Guard (USCG). The total costs of a port state control inspection vary considerably, depending in particular on the country where they are performed. In Australia, for example, port state control inspectors sometimes have to travel far to reach vessels in remote areas and, according to AMSA, travel costs can be as high as USD 2,000 in remote areas. The time allocated on board can also vary depending on the type of inspection. If the ship is detained, the inspection can take much longer and the costs will increase considerably.

We wish to stress that the TECS values in Tables 6-8 cannot be compared directly with the inspection costs in Table 9, because the reported inspection costs do not include other costs that the ship owner faces, such as regular maintenance costs to ensure an adequate level of safety.. Further, in finding a balance between costs and benefits of inspections, the benefits 
depend on the evaluation of reductions of small risk involving very large values. It is known from the literature on economic decision making that it is not an easy task to take decisions in high value, small probability situations, see, for example, McClelland et al [33] and Wakker et al [34]. From the reported cost savings in Tables 6-8, one can however conclude the following. Given the fact that inspection capacities are limited, targeting of high risk vessels for inspections is very important to realize maximum cost savings.

Table 9: Average costs per inspection (in USD)

\begin{tabular}{|l|r|r|r|}
\hline Inspection type & $\begin{array}{r}\text { Shore-side } \\
\text { costs }\end{array}$ & $\begin{array}{r}\text { Ship-side } \\
\text { costs }\end{array}$ & $\begin{array}{r}\text { Total costs per } \\
\text { inspection }\end{array}$ \\
\hline PSC - Australia & 950 & 288 & 1,238 \\
PSC - United Kingdom & 747 & 288 & 1,035 \\
PSC - United States & 1,250 & 288 & 1,538 \\
Class annual survey & 10,362 & 517 & 10,879 \\
P\&I Club inspection & 3,048 & 441 & 3,489 \\
Flag inspection & 747 & 441 & 1,188 \\
Vetting inspection - tanker & 4,384 & 566 & 4,950 \\
Vetting inspection - dry bulk & 6,250 & 566 & 6,816 \\
\hline
\end{tabular}

Note: Shore side costs include $20 \%$ administrative costs.

\section{Conclusion}

We use a unique dataset of vessel arrivals and of both port state control and vetting inspection information to quantify the reduction in risk due to an inspection. The total estimated cost savings (TECS) of the prevention of incidents are based on the total insured value (TIV), which represents the total value that can be insured and which comprises hull and machinery, cargo values, third party liability, and pollution liability limits. The risk reduction owing to inspections is determined by calculating survival gains based on hazard models. We estimate also a lower bound of TECS, which is obtained by adjusting TIV by estimated probabilities of various aspects of incidents. As an alternative to TIV, we consider also premium and historical claim figures as base values, but we find that TIV provides a more accurate basis to determine TECS per ship type. The outcomes of our models confirm the risk reducing effect of port state control and industry vetting inspections for all five considered ship types. ${ }^{19}$

The average monetary benefits of the reduced risk of total loss of ships realized by a port state control inspection, as measured by TIV-based TECS, vary from USD 74 to 192.8 thousand (median value of USD 18.9 to 45.9 thousand). For industry inspections, the range runs from USD 93.5 to 169.5 thousand (median values of USD 16.8 to 33.1 thousand) for dry bulk, and from USD 136.7 to 379.0 thousand (median values of USD 43.6 to 131 thousand) for tankers. It is not surprising that the cost savings of industry inspections are higher, especially for tankers, since the effect of industry inspections is stronger and these inspections are also much more extensive than port state control inspections. For dry bulk carriers, the cost savings of industry inspections are lower than for tankers which are caused by the relatively lower TIV values for dry bulk carriers. For port state control inspections, based on our upper bound average TECS, general cargo vessels are second in line, after passenger vessels. This ranking is changed when we base our cost savings on the lower bound TECS values, when general cargo vessels have the highest value. Cost savings

\footnotetext{
${ }^{19}$ This result was not confirmed (and neither denied) for the rest category of "other ship types"; these results can be obtained from the authors.
} 
increase with age, except for passenger vessels. For average TECS, the older age brackets show highest costs savings, especially for industry inspections on tankers. As concerns size, TECS is highest for ships of 30 to 40 thousand gt. Further, cost savings are higher for undefined flags and unknown classification societies. It is noteworthy that white listed flags or IACS class do not always present the lowest values.

The analysis of this paper can be extended in the future, for example, by building up an even larger arrival and casualty dataset than the one employed here. Extensions of interest are the inclusion of arrival data from more than two regions and duration models for various types of casualty, including the types of very serious casualties and serious casualties. Another line of research that we are currently pursuing is to develop and test alternative selection strategies to target ships for inspections, so as to optimize the returns of inspections in terms of saving future accident costs.

\section{Acknowledgements}

We thank the United States Coast Guard and the Australian Maritime Safety Authority for their arrival and inspection data. We also thank RightShip, CDI, and OCIMF for the vetting inspection data, and Lloyd's Register Fairplay for the casualty data. We acknowledge two anonymous data providers from the P\&I Clubs. We thank in particular Mr. Andrew Higgs for his very valuable input in determining the components of the TIV value, and Capt. John Koster from the USCG for his initial ideas that have inspired our research reported in this article.

\section{References}

[1] United Nations Conference on Trade and Development (2009), Review of Maritime Transport, New York.

[2] Lloyd's Register Fairplay - World Fleet Statistics 1999-2008.

[3] Bijwaard, G.E., and S. Knapp (2009), Analysis of ship life cycles - The impact of economic cycles and ship inspections, Marine Policy 33, 350-369.

[4] Knapp, S., and P.H. Franses (2009), Comprehensive review of the maritime safety regimes - Present status and recommendations for improvements, Transport Reviews 30, 241-270.

[5] Knapp, S., and P.H. Franses (2007), Econometric analysis on the effect of port state control inspections on the probability of casualty, Marine Policy 31, 550-563.

[6] Knapp, S., and P.H. Franses (2007), A global view on port state control - Econometric analysis of the differences across port state control regimes, Maritime Policy and Management 34, 453-483.

[7] Knapp, S., and P.H. Franses (2007), Econometric analysis to differentiate effects of various ship safety inspections, Marine Policy 32, 653-662.

[8] Carriou, P., M.Q. Mejia, and F.C. Wolff (2007), On the effectiveness of port state control inspections, Transportation Research Part E, doi:10.1016/j.tre.2006.11.005.

[9] Payoyo, P.B. (1994), Implementation of international conventions through port state control: An assessment, Marine Policy 18, 379-392.

[10] Wood, J. (1995), Opa 90, Maritime Policy and Management 22, 201-208.

[11] Talley, K.W. (2002), Vessel damage cost differentials: Bulk, container and tanker accidents, International Journal of Maritime Economics 4, 307-322.

[12] Talley, K.W. (1999), Determinants of the property damage costs of tanker accidents, Transportation Research Part D 4, 413-426. 
[13] Goulielmos, A.M., and K. Giziakis (1998), Treatment of uncompensated cost of marine accidents in a model of welfare economics, Disaster Prevention and Management 7, 183-187. [14] Skong, R. (2002), Risk acceptance criteria: Current proposals and IMO position, Conference on Surface Transport Technologies for Sustainable Development, Valencia, Spain, June 4-6.

[15] IMO, MSC 83/Inf.2, May 14 2007, Formal Safety Assessment-Consolidated Text of the Guidelines for Formal Safety Assessment for Use in the IMO Rule-making Process, London. [16] SAFEDOR, Risk Evaluation Criteria, European Commission Project funded under the Sixth Framework Programme (2002-2006), 2007.

[17] Grigalunas, T.A., and J.J. Opaluch (1988), A natural resource damage assessment model for coastal and marine environments, GeoJournal 16, 315-321.

[18] Grey, C.J. (1999), The cost of oil spills from tankers: An analysis of IOPC fund incidents, Proceeding of the International Oil Spill Conference, www.itopf.com/costs.html [19] Knapp, S. (2006), The econometrics of maritime safety - Recommendations to enhance safety at sea, Doctoral Thesis, Erasmus Research Institute of Management, Erasmus University, Rotterdam, http://hdl.handle.net/1765/7913

[20] The 2008 Cefor NoMIS Report, Nordic Marine Insurance Statistics, http://www.cefor.no/statistics/statistics.htm

[21] Ship Operating Costs Annual Review and Forecast - 2008/09, Drewry Shipping Consultants, London, July 2008.

[22] Shipping Intelligence Network, Clarksons, http://www.clarksons.net

[23] International Oil Pollution Compensation Funds, Problems associated with interim payments, IOPC/APR10/5/4, 5 March 2010, London.

[24] International Oil Pollution Compensation Fund 1992, Claims Manual, December 2008

Edition.

[25] United Nations Commodity Trade Statistics database, http://www.undata.org

[26] United Nations Conference on Trade and Development, Review of Maritime Transport, 2007, 2006, 2004, 2003, 2001 and 2000 edition, New York.

[27] Hoffman, J. (2008), The model split of international goods transport, UNCTAD

Transport Newsletter, No 38.

[28] Second IMO Greenhouse Gas Study 2009, International Maritime Organization (IMO), London, UK, April 2009.

[29] Athens Convention relating to the Carriage of Passengers and their Luggage by Sea

(PAL), 1974, www.imo.org

[30] Van den Berg, G. J. (2001), Duration models: Specification, identification and multiple durations, in J. J. Heckman and E. Leamer, eds., Handbook of econometrics, Vol. 5,

Amsterdam: Elsevier Science, pp. 3381-3460.

[31] IMO, MSC/Circ. 953, MEPC/Circ. 372, Reports on Marine Casualties and Incidents, Revised harmonized reporting procedures, adopted $14^{\text {th }}$ December 2000, IMO, London.

[32] IMO, MSC Resolution MSC.255(84), Casualty Investigation Code, adopted 16 May 2008, IMO, London.

[33] McClelland, G.H., W.D. Schulze, D.L. Coursey (1993), Insurance for low-probability hazards: A bimodal response to unlikely events, Journal of Risk and Uncertainty 7, 35-51.

[34] Wakker, P.P., R.H. Thaler, and A. Tversky (1997), Probabilistic insurance, Journal of Risk and Uncertainty 15, 7-28.

[35] Greene, H.W. (2008), Econometric Analysis (6-th ed.), Prentice-Hall, New Jersey. 
Appendix 1.A: Results of hazard models for general cargo ships

\begin{tabular}{|c|c|c|c|c|c|c|c|c|c|c|c|c|c|c|c|}
\hline \multirow[b]{2}{*}{ Variables } & \multicolumn{3}{|c|}{ Up to $31 / 12 / 2003$} & \multicolumn{3}{|c|}{ Up to $31 / 12 / 2004$} & \multicolumn{3}{|c|}{ Up to $31 / 12 / 2005$} & \multicolumn{3}{|c|}{ Up to $31 / 12 / 2006$} & \multicolumn{3}{|c|}{ Up to $31 / 12 / 2007$} \\
\hline & Coef & SE & Sig & Coef & SE & Sig & Coef & SE & Sig & Coef & SE & Sig & Coef & SE & Sig \\
\hline Tonnage (ln) & 0.386 & 0.035 & $* *$ & 0.300 & 0.030 & $* *$ & 0.273 & 0.028 & $* *$ & 0.264 & 0.025 & $* *$ & 0.257 & 0.024 & $* *$ \\
\hline Port state control inspection & -0.179 & 0.114 & & -0.325 & 0.109 & $* *$ & -0.477 & 0.099 & $* *$ & -0.418 & 0.086 & $* *$ & -0.369 & 0.079 & $* *$ \\
\hline Detained & 0.074 & 0.401 & & -0.119 & 0.404 & & -0.076 & 0.327 & & 0.126 & 0.245 & & -0.040 & 0.233 & \\
\hline Total deficiencies & 0.040 & 0.219 & & 0.186 & 0.179 & & 0.211 & 0.153 & & 0.196 & 0.109 & $\wedge$ & 0.282 & 0.088 & $* *$ \\
\hline Change of Flag & 0.492 & 0.141 & & -0.032 & 0.129 & & -0.111 & 0.125 & & -0.166 & 0.121 & & -0.160 & 0.119 & \\
\hline Change of DoC company & $\mathrm{n} / \mathrm{a}$ & & & -0.548 & 0.282 & & -0.155 & 0.234 & & -0.692 & 0.159 & $* *$ & -0.784 & 0.137 & $* *$ \\
\hline Less serious casualty (180 days) & $\mathrm{n} / \mathrm{a}$ & & & $\mathrm{n} / \mathrm{a}$ & & & -1.273 & 0.995 & & -0.402 & 0.572 & & -0.433 & 0.572 & \\
\hline Less serious casualty ( 360 days) & -0.610 & 0.556 & & -0.760 & 0.561 & & -1.429 & 0.559 & & -0.326 & 0.565 & & -0.398 & 0.567 & \\
\hline Serious casualty (180 days) & $\mathrm{n} / \mathrm{a}$ & & & -0.476 & 0.704 & & -0.397 & 0.580 & & -0.034 & 0.578 & & -0.053 & 0.578 & \\
\hline Serious casualty (360 days) & 0.224 & 0.575 & & 0.036 & 0.576 & & -0.046 & 0.577 & & -0.056 & 0.576 & & -0.077 & 0.575 & \\
\hline Very serious casualty (180 days) & 1.988 & 0.337 & $* *$ & 1.931 & 0.335 & $* *$ & 2.286 & 0.257 & $* *$ & 2.195 & 0.229 & $* *$ & 2.178 & 0.228 & $* *$ \\
\hline Very serious casualty (360 days) & 1.976 & 0.266 & $* *$ & 1.898 & 0.270 & $* *$ & 1.844 & 0.272 & $* *$ & 1.688 & 0.268 & $* *$ & 1.704 & 0.261 & $* *$ \\
\hline Flag - black & 0.206 & 0.814 & $*$ & 0.291 & 0.075 & $* *$ & 0.322 & 0.073 & $* *$ & 0.385 & 0.071 & $* *$ & 0.399 & 0.069 & $* *$ \\
\hline Flag - grey & -0.127 & 0.107 & & -0.006 & 0.096 & & 0.070 & 0.093 & & 0.111 & 0.090 & & 0.127 & 0.087 & \\
\hline Flag - undefined & 0.195 & 0.124 & & 0.177 & 0.116 & & 0.187 & 0.111 & $\wedge$ & 0.272 & 0.104 & $* *$ & 0.272 & 0.100 & $* *$ \\
\hline Flag - white & $\mathrm{BM}$ & & & $\mathrm{BM}$ & & & $\mathrm{BM}$ & & & $\mathrm{BM}$ & & & $\mathrm{BM}$ & & \\
\hline Classification society - IACS & 0.823 & 0.118 & $* *$ & 0.877 & 0.106 & $* *$ & 0.862 & 0.100 & $* *$ & 0.665 & 0.089 & $* *$ & 0.629 & 0.085 & $* *$ \\
\hline Classification society - NIACS & -0.081 & 0.148 & & 0.099 & 0.130 & & 0.109 & 0.122 & & -0.060 & 0.110 & & -0.054 & 0.105 & \\
\hline Classification society - Unknown & $\mathrm{BM}$ & & & $\mathrm{BM}$ & & & $\mathrm{BM}$ & & & $\mathrm{BM}$ & & & $\mathrm{BM}$ & & \\
\hline DoC company - EEUR & 0.364 & 1.084 & & 0.461 & 0.558 & & 0.134 & 0.484 & & 0.052 & 0.381 & & -0.145 & 0.356 & \\
\hline DoC company - DEVC & 1.191 & 0.495 & $*$ & 0.565 & 0.308 & $\wedge$ & 0.414 & 0.244 & $\wedge$ & 0.249 & 0.198 & & 0.268 & 0.171 & \\
\hline DoC company - LSDC & 2.072 & 1.089 & $\wedge$ & 0.914 & 1.032 & & 0.325 & 1.020 & & 1.428 & 0.426 & $* *$ & 1.165 & 0.427 & $* *$ \\
\hline DoC company - Unknown & 3.585 & 0.413 & $* *$ & 2.586 & 0.237 & $* *$ & 2.197 & 0.182 & $* *$ & 1.823 & 0.142 & $* *$ & 1.649 & 0.125 & $* *$ \\
\hline DoC company - OECD & $\mathrm{BM}$ & & & $\mathrm{BM}$ & & & $\mathrm{BM}$ & & & $\mathrm{BM}$ & & & BM & & \\
\hline Earnings (ln) & 0.553 & 0.099 & $* *$ & 0.252 & 0.078 & $* *$ & -0.002 & 0.070 & & -0.042 & 0.067 & & -0.453 & 0.064 & \\
\hline Age: $0-4$ years & $\mathrm{BM}$ & & & $\mathrm{BM}$ & & & $\mathrm{BM}$ & & & $\mathrm{BM}$ & & & $\mathrm{BM}$ & & \\
\hline Age: $5-10$ years & -1.072 & 0.281 & $* *$ & -1.079 & 0.248 & $* *$ & -0.924 & 0.227 & $* *$ & -1.083 & 0.215 & $* *$ & -0.977 & 0.210 & $* *$ \\
\hline Age: $11-15$ years 3 & -0.585 & 0.242 & $*$ & -0.670 & 0.214 & $* *$ & -0.645 & 0.201 & $* *$ & -0.795 & 0.187 & $* *$ & -0.748 & 0.186 & $* *$ \\
\hline Age: $16-20$ years & 0.309 & 0.196 & & 0.260 & 0.169 & & 0.196 & 0.161 & & 0.031 & 0.147 & & 0.092 & 0.146 & \\
\hline Age: $21-25$ years & 1.681 & 0.172 & $* *$ & 1.477 & 0.151 & $* *$ & 1.439 & 0.142 & $* *$ & 1.281 & 0.127 & $* *$ & 1.345 & 0.126 & $* *$ \\
\hline Age: above 25 years & 1.580 & 1.872 & $* *$ & 1.427 & 0.161 & $* *$ & 1.363 & 0.150 & $* *$ & 1.324 & 0.132 & $* *$ & 1.463 & 0.130 & $* *$ \\
\hline Constant & -12.451 & 0.602 & & -10.703 & 0.436 & & -10.150 & 0.390 & & -9.466 & 0.342 & & -9.312 & 0.320 & \\
\hline Number of arrivals & 16,197 & & & 16,674 & & & 17,093 & & & 17,452 & & & 17,452 & & \\
\hline
\end{tabular}


Appendix 1.B: Results of hazard models for dry bulk carriers

\begin{tabular}{|c|c|c|c|c|c|c|c|c|c|c|c|c|c|c|c|}
\hline \multirow[b]{2}{*}{ Variables } & \multicolumn{3}{|c|}{ Up to $31 / 12 / 2003$} & \multicolumn{3}{|c|}{ Up to $31 / 12 / 2004$} & \multicolumn{3}{|c|}{ Up to $31 / 12 / 2005$} & \multicolumn{3}{|c|}{ Up to $31 / 12 / 2006$} & \multicolumn{3}{|c|}{ Up to $31 / 12 / 2007$} \\
\hline & Coef & SE & Sig & Coef & SE & Sig & Coef & SE & Sig & Coef & SE & Sig & Coef & SE & Sig \\
\hline Tonnage (ln) & 0.698 & 0.092 & $* *$ & 0.671 & 0.086 & $* *$ & 0.637 & 0.082 & $* *$ & 0.609 & 0.074 & $* *$ & 0.578 & 0.071 & $* *$ \\
\hline Port state control inspection & -1.046 & 0.194 & $* *$ & -0.994 & 0.188 & $* *$ & -1.034 & 0.169 & $* *$ & -0.751 & 0.134 & $* *$ & -0.721 & 0.129 & $* *$ \\
\hline RightShip inspection & -0.927 & 0.598 & & -1.091 & 0.599 & $\wedge$ & -1.138 & 0.525 & $*$ & -0.865 & 0.348 & * & -0.946 & 0.331 & $* *$ \\
\hline Detained & -0.677 & 1.019 & & -0.715 & 1.017 & & 1.100 & 0.490 & $*$ & 0.566 & 0.430 & & 0.800 & 0.310 & $*$ \\
\hline Total deficiencies & $\mathrm{n} / \mathrm{a}$ & & & $\mathrm{n} / \mathrm{a}$ & & & -1.195 & 0.509 & $*$ & -0.285 & 0.223 & & -0.025 & 0.143 & \\
\hline Change of Flag & -0.480 & 0.344 & & -0.164 & 0.278 & & 0.110 & 0.221 & & -0.159 & 0.206 & & -0.015 & 0.206 & \\
\hline Change of DoC company & $\mathrm{n} / \mathrm{a}$ & & & -1.380 & 0.725 & $\wedge$ & -0.996 & 0.591 & $\wedge$ & -1.607 & 0.413 & $* *$ & -1.900 & 0.415 & $* *$ \\
\hline Less serious casualty (180 days) & $\mathrm{n} / \mathrm{a}$ & & & $\mathrm{n} / \mathrm{a}$ & & & $\mathrm{n} / \mathrm{a}$ & & & $\mathrm{n} / \mathrm{a}$ & & & $\mathrm{n} / \mathrm{a}$ & & \\
\hline Less serious casualty ( 360 days) & -0.254 & 0.705 & & -0.279 & 0.710 & & -0.359 & 0.712 & & -0.642 & 0.715 & & -0.681 & 0.715 & \\
\hline Serious casualty (180 days) & $\mathrm{n} / \mathrm{a}$ & & & $\mathrm{n} / \mathrm{a}$ & & & -1.162 & 1.030 & & -0.206 & 1.010 & & -0.181 & 1.009 & \\
\hline Serious casualty ( 360 days) & -0.832 & 1.057 & & -0.888 & 1.041 & & -0.288 & 1.035 & & -0.407 & 1.022 & & -0.401 & 1.021 & \\
\hline Very serious casualty (180 days) & 1.148 & 1.074 & & 1.068 & 1.060 & & 0.586 & 1.042 & & 0.116 & 1.027 & & 0.092 & 1.028 & \\
\hline Very serious casualty (360 days) & 0.313 & 0.955 & & 0.307 & 0.961 & & 0.224 & 0.979 & & 0.001 & 0.971 & & -0.027 & 0.974 & \\
\hline Flag - black & 0.257 & 0.122 & $*$ & 0.249 & 0.118 & * & 0.287 & 0.114 & $*$ & 0.343 & 0.107 & $* *$ & 0.394 & 0.107 & $* *$ \\
\hline Flag - grey & 0.086 & 0.202 & & 0.186 & 0.185 & & 0.223 & 0.182 & & 0.164 & 0.179 & & 0.164 & 0.179 & \\
\hline Flag - undefined & -0.182 & 0.226 & & -0.047 & 0.206 & & 0.055 & 0.192 & & 0.096 & 0.182 & & 0.106 & 0.183 & \\
\hline Flag - white & $\mathrm{BM}$ & & & $\mathrm{BM}$ & & & $\mathrm{BM}$ & & & $\mathrm{BM}$ & & & $\mathrm{BM}$ & & \\
\hline Classification society - IACS & -0.234 & 0.183 & & -0.298 & 0.176 & $\wedge$ & -0.375 & 0.167 & $*$ & -0.478 & 0.153 & $* *$ & -0.509 & 0.146 & $* *$ \\
\hline Classification society - NIACS & -0.237 & 0.250 & & -0.410 & 0.248 & $\wedge$ & -0.524 & 0.237 & $*$ & -0.473 & 0.209 & $*$ & -0.482 & 0.199 & $*$ \\
\hline Classification society - Unknown & $\mathrm{BM}$ & & & $\mathrm{BM}$ & & & $\mathrm{BM}$ & & & $\mathrm{BM}$ & & & $\mathrm{BM}$ & & \\
\hline DoC company - EEUR & $\mathrm{n} / \mathrm{a}$ & & & $\mathrm{n} / \mathrm{a}$ & & & 0.489 & 1.035 & & -0.364 & 1.015 & & 0.191 & 0.727 & \\
\hline DoC company - DEVC & 0.309 & 0.589 & & 0.379 & 0.544 & & -0.068 & 0.464 & & -0.251 & 0.324 & & -0.099 & 0.287 & \\
\hline DoC company - LSDC & $\mathrm{n} / \mathrm{a}$ & & & $\mathrm{n} / \mathrm{a}$ & & & $\mathrm{n} / \mathrm{a}$ & & & $\mathrm{n} / \mathrm{a}$ & & & $\mathrm{n} / \mathrm{a}$ & & \\
\hline DoC company - Unknown & 2.671 & 0.385 & $* *$ & 2.663 & 0.359 & $* *$ & 2.249 & 0.268 & $* *$ & 1.685 & 0.176 & $* *$ & 1.654 & 0.168 & $* *$ \\
\hline DoC company - OECD & $\mathrm{BM}$ & & & $\mathrm{BM}$ & & & $\mathrm{BM}$ & & & $\mathrm{BM}$ & & & BM & & \\
\hline Earnings $(\ln )$ & 0.825 & 0.173 & $* *$ & 0.007 & 0.106 & & -0.123 & 0.093 & & -0.110 & 0.083 & & -0.166 & 0.077 & $*$ \\
\hline Age: $0-4$ years & $\mathrm{BM}$ & & & $\mathrm{BM}$ & & & $\mathrm{BM}$ & & & $\mathrm{BM}$ & & & $\mathrm{BM}$ & & \\
\hline Age: $5-10$ years & -0.729 & 0.581 & & -0.642 & 0.470 & & -0.898 & 0.416 & $*$ & -0.983 & 0.363 & $* *$ & -0.988 & 0.363 & $* *$ \\
\hline Age: $11-15$ years 3 & 0.037 & 0.514 & & -0.320 & 0.475 & & -0.746 & 0.446 & $\wedge$ & -1.057 & 0.434 & $*$ & -1.083 & 0.434 & $*$ \\
\hline Age: $16-20$ years & 0.642 & 0.380 & $\wedge$ & 0.352 & 0.324 & & -0.051 & 0.279 & & -0.276 & 0.257 & & -0.291 & 0.256 & \\
\hline Age: $21-25$ years & 2.572 & 0.328 & $* *$ & 2.287 & 0.266 & $* *$ & 1.877 & 0.210 & $* *$ & 1.615 & 0.181 & $* *$ & 1.594 & 0.178 & $* *$ \\
\hline Age: above 25 years & 3.115 & 0.336 & $* *$ & 2.850 & 0.277 & $* *$ & 2.446 & 0.224 & $* *$ & 2.319 & 0.193 & $* *$ & 2.312 & 0.190 & $* *$ \\
\hline Constant & -14.566 & 1.156 & & -14.377 & 1.062 & & -13.287 & 0.976 & & -12.223 & 0.861 & & -11.917 & 0.831 & \\
\hline Number of arrivals & 6,498 & & & 6,883 & & & 7,017 & & & 7,208 & & & 7,211 & & \\
\hline
\end{tabular}

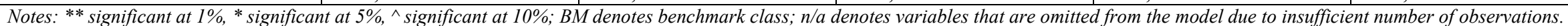


Appendix 1.C: Results of hazard models for container ships

\begin{tabular}{|c|c|c|c|c|c|c|c|c|c|c|c|c|c|c|c|}
\hline \multirow[b]{2}{*}{ Variables } & \multicolumn{3}{|c|}{ Up to $31 / 12 / 2003$} & \multicolumn{3}{|c|}{ Up to $31 / 12 / 2004$} & \multicolumn{3}{|c|}{ Up to $31 / 12 / 2005$} & \multicolumn{3}{|c|}{ Up to $31 / 12 / 2006$} & \multicolumn{3}{|c|}{ Up to $31 / 12 / 2007$} \\
\hline & Coef & SE & Sig & Coef & SE & Sig & Coef & SE & Sig & Coef & SE & Sig & Coef & SE & Sig \\
\hline Tonnage (ln) & 0.544 & 0.107 & $* *$ & 0.743 & 0.101 & $* *$ & 0.636 & 0.097 & $* *$ & 0.572 & 0.086 & $* *$ & 0.585 & 0.077 & $* *$ \\
\hline Port state control inspection & -1.103 & 0.354 & $* *$ & -0.695 & 0.343 & $*$ & -0.755 & 0.308 & $*$ & -0.471 & 0.235 & $*$ & -0.402 & 0.198 & $*$ \\
\hline Detained & 2.060 & 0.828 & $*$ & 2.453 & 0.811 & $* *$ & 1.848 & 0.758 & $*$ & 1.150 & 0.708 & & 0.762 & 0.657 & \\
\hline Total deficiencies & -0.311 & 0.818 & & -0.677 & 0.840 & & -0.777 & 0.724 & & -1.145 & 0.773 & & 0.058 & 0.345 & \\
\hline Change of Flag & -0.245 & 0.352 & & 0.060 & 0.334 & & 0.004 & 0.328 & & -0.098 & 0.312 & & -0.068 & 0.299 & \\
\hline Change of DoC company & $\mathrm{n} / \mathrm{a}$ & & & -0.777 & 0.756 & & -0.308 & 0.598 & & -1.085 & 0.466 & $*$ & -0.975 & 0.346 & $* *$ \\
\hline Less serious casualty (180 days) & $\mathrm{n} / \mathrm{a}$ & & & $\mathrm{n} / \mathrm{a}$ & & & $\mathrm{n} / \mathrm{a}$ & & & $\mathrm{n} / \mathrm{a}$ & & & $\mathrm{n} / \mathrm{a}$ & & \\
\hline Less serious casualty ( 360 days) & $\mathrm{n} / \mathrm{a}$ & & & $\mathrm{n} / \mathrm{a}$ & & & $\mathrm{n} / \mathrm{a}$ & & & $\mathrm{n} / \mathrm{a}$ & & & $\mathrm{n} / \mathrm{a}$ & & \\
\hline Serious casualty (180 days) & $\mathrm{n} / \mathrm{a}$ & & & $\mathrm{n} / \mathrm{a}$ & & & $\mathrm{n} / \mathrm{a}$ & & & $\mathrm{n} / \mathrm{a}$ & & & $\mathrm{n} / \mathrm{a}$ & & \\
\hline Serious casualty (360 days) & 0.125 & 0.983 & & 0.027 & 1.016 & & 0.099 & 0.996 & & 0.129 & 0.987 & & 0.043 & 0.988 & $*$ \\
\hline Very serious casualty (180 days) & $\mathrm{n} / \mathrm{a}$ & & & $\mathrm{n} / \mathrm{a}$ & & & $\mathrm{n} / \mathrm{a}$ & & & $\mathrm{n} / \mathrm{a}$ & & & $\mathrm{n} / \mathrm{a}$ & & \\
\hline Very serious casualty (360 days) & $\mathrm{n} / \mathrm{a}$ & & & $\mathrm{n} / \mathrm{a}$ & & & $\mathrm{n} / \mathrm{a}$ & & & $\mathrm{n} / \mathrm{a}$ & & & $\mathrm{n} / \mathrm{a}$ & & \\
\hline Flag - black & -0.194 & 0.178 & & -0.256 & 0.163 & & -0.191 & 0.159 & & -0.029 & 0.154 & & -0.002 & 0.145 & \\
\hline Flag - grey & -0.342 & 0.244 & & 0.002 & 0.216 & & 0.044 & 0.208 & & 0.099 & 0.202 & & 0.036 & 0.192 & \\
\hline Flag - undefined & 0.271 & 0.327 & & 0.078 & 0.291 & & -0.041 & 0.296 & & 0.189 & 0.272 & & 0.287 & 0.249 & \\
\hline Flag - white & $\mathrm{BM}$ & & & $\mathrm{BM}$ & & & $\mathrm{BM}$ & & & $\mathrm{BM}$ & & & $\mathrm{BM}$ & & \\
\hline Classification society - IACS & 0.057 & 0.379 & & 0.448 & 0.375 & & 0.201 & 0.344 & & 0.192 & 0.333 & & 0.230 & 0.322 & \\
\hline Classification society - NIACS & -0.857 & 0.574 & & -0.680 & 0.528 & & -0.843 & 0.500 & $\wedge$ & -0.456 & 0.432 & & -0.371 & 0.410 & \\
\hline Classification society - Unknown & BM & & & $\mathrm{BM}$ & & & $\mathrm{BM}$ & & & $\mathrm{BM}$ & & & $\mathrm{BM}$ & & \\
\hline DoC company - EEUR & $\mathrm{n} / \mathrm{a}$ & & & $\mathrm{n} / \mathrm{a}$ & & & $\mathrm{n} / \mathrm{a}$ & & & $\mathrm{n} / \mathrm{a}$ & & & $\mathrm{n} / \mathrm{a}$ & & \\
\hline DoC company - DEVC & $\mathrm{n} / \mathrm{a}$ & & & 0.481 & 0.879 & & 0.418 & 0.619 & & 0.301 & 0.453 & & 0.580 & 0.317 & $\wedge$ \\
\hline DoC company - LSDC & $\mathrm{n} / \mathrm{a}$ & & & $\mathrm{n} / \mathrm{a}$ & & & $\mathrm{n} / \mathrm{a}$ & & & 2.233 & 0.734 & $* *$ & 1.610 & 0.734 & $*$ \\
\hline DoC company - Unknown & $\mathrm{n} / \mathrm{a}$ & & & 3.312 & 0.509 & $* *$ & 2.728 & 0.368 & $* *$ & 2.114 & 0.261 & $* *$ & 1.731 & 0.207 & $* *$ \\
\hline DoC company - OECD & BM & & & $\mathrm{BM}$ & & & $\mathrm{BM}$ & & & $\mathrm{BM}$ & $\mathrm{n} / \mathrm{a}$ & & $\mathrm{BM}$ & & \\
\hline Earnings (ln) & 0.767 & 0.580 & & 0.298 & 0.400 & & -0.190 & 0.290 & & -0.198 & 0.260 & & -0.260 & 0.238 & \\
\hline Age: $0-4$ years & $\mathrm{BM}$ & & & $\mathrm{BM}$ & & & $\mathrm{BM}$ & & & $\mathrm{BM}$ & & & $\mathrm{BM}$ & & \\
\hline Age: $5-10$ years & -1.630 & 1.081 & & -1.681 & 1.054 & & -1.179 & 0.759 & & -1.340 & 0.757 & $\wedge$ & -1.355 & 0.759 & $\wedge$ \\
\hline Age: $11-15$ years 3 & -1.630 & 1.081 & & -1.123 & 1.040 & & -1.308 & 1.033 & & -1.477 & 1.028 & & -1.490 & 1.029 & \\
\hline Age: $16-20$ years & 1.014 & 0.589 & $\wedge$ & 0.447 & 0.550 & & 0.294 & 0.533 & & 0.329 & 0.492 & & 0.521 & 0.467 & \\
\hline Age: $21-25$ years & 3.903 & 0.406 & $* *$ & 3.229 & 0.337 & $* *$ & 3.049 & 0.311 & $* *$ & 2.956 & 0.294 & $* *$ & 3.059 & 0.292 & $* *$ \\
\hline Age: above 25 years & 4.071 & 0.426 & $* *$ & 3.560 & 0.354 & $* *$ & 3.289 & 0.328 & $* *$ & 3.317 & 0.312 & $* *$ & 3.625 & 0.305 & $* *$ \\
\hline Constant & -11.522 & 1.268 & & -16.461 & 1.334 & & -14.863 & 1.246 & & -13.742 & 1.085 & & -13.786 & 0.985 & \\
\hline Number of arrivals & 4,340 & & & 4,761 & & & 4,842 & & & 5,045 & & & 5,047 & & \\
\hline
\end{tabular}

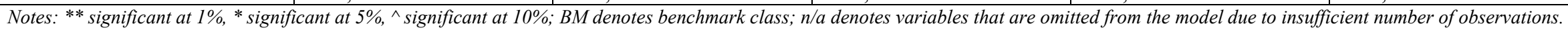


Appendix 1.D: Results of hazard models for tankers

\begin{tabular}{|c|c|c|c|c|c|c|c|c|c|c|c|c|c|c|c|}
\hline \multirow[b]{2}{*}{ Variables } & \multicolumn{3}{|c|}{ Up to $31 / 12 / 2003$} & \multicolumn{3}{|c|}{ Up to $31 / 12 / 2004$} & \multicolumn{3}{|c|}{ Up to $31 / 12 / 2005$} & \multicolumn{3}{|c|}{ Up to $31 / 12 / 2006$} & \multicolumn{3}{|c|}{ Up to $31 / 12 / 2007$} \\
\hline & Coef & SE & Sig & Coef & SE & Sig & Coef & SE & Sig & Coef & SE & Sig & Coef & SE & Sig \\
\hline Tonnage (ln) & 0.509 & 0.028 & $* *$ & 0.439 & 0.023 & $* *$ & 0.429 & 0.021 & $* *$ & 0.399 & 0.020 & $* *$ & 0.412 & 0.019 & $* *$ \\
\hline Port state control inspection & -0.385 & 0.167 & $*$ & -0.359 & 0.133 & $* *$ & -0.412 & 0.120 & $* *$ & -0.275 & 0.103 & $* *$ & -0.087 & 0.091 & \\
\hline OCIMF/SIRE inspection & -0.767 & 0.368 & $*$ & -0.425 & 0.246 & $\wedge$ & -0.560 & 0.235 & $*$ & -0.735 & 0.211 & $* *$ & -0.640 & 0.166 & $* *$ \\
\hline Detained & -0.815 & 1.407 & & -0.216 & 0.853 & & 0.014 & 0.673 & & 0.633 & 0.396 & & 0.531 & 0.366 & \\
\hline Total deficiencies & 0.342 & 0.400 & & -0.099 & 0.432 & & -0.453 & 0.483 & & -0.512 & 0.281 & $\wedge$ & -0.063 & 0.200 & \\
\hline Change of Flag & -0.401 & 0.249 & & -0.089 & 0.174 & & -0.086 & 0.155 & & -0.201 & 0.145 & & -0.251 & 0.143 & $\wedge$ \\
\hline Change of DoC company & $\mathrm{n} / \mathrm{a}$ & & & 0.274 & 0.225 & & 0.098 & 0.199 & & -0.311 & 0.137 & $*$ & -0.391 & 0.116 & $* *$ \\
\hline Less serious casualty (180 days) & $\mathrm{n} / \mathrm{a}$ & & & -0.460 & 0.998 & & -0.788 & 1.023 & & -1.023 & 1.026 & & -1.122 & 1.028 & \\
\hline Less serious casualty ( 360 days) & $\mathrm{n} / \mathrm{a}$ & & & 0.722 & 0.488 & & 0.566 & 0.497 & & 0.771 & 0.373 & $*$ & 0.632 & 0.377 & $\wedge$ \\
\hline Serious casualty ( 180 days) & $\mathrm{n} / \mathrm{a}$ & & & -0.421 & 0.942 & & -0.444 & 0.955 & & -0.454 & 0.971 & & -0.540 & 0.970 & \\
\hline Serious casualty ( 360 days) & $\mathrm{n} / \mathrm{a}$ & & & 1.404 & 0.473 & $* *$ & 1.189 & 0.465 & $*$ & 1.111 & 0.461 & $*$ & 1.032 & 0.459 & $*$ \\
\hline Very serious casualty (180 days) & $\mathrm{n} / \mathrm{a}$ & & & 0.433 & 0.904 & $* *$ & 0.738 & 0.709 & & 0.356 & 0.716 & & 0.225 & 0.720 & \\
\hline Very serious casualty (360 days) & $\mathrm{n} / \mathrm{a}$ & & & 0.386 & 1.055 & & 1.367 & 0.645 & $*$ & 1.276 & 0.478 & $* *$ & 1.326 & 0.435 & $* *$ \\
\hline Flag - black & 0.114 & 0.083 & & 0.210 & 0.070 & $* *$ & 0.233 & 0.066 & $* *$ & 0.210 & 0.062 & $* *$ & 0.187 & 0.060 & $* *$ \\
\hline Flag - grey & 0.021 & 0.128 & & -0.195 & 0.116 & $\wedge$ & -0.230 & 0.105 & $*$ & -0.329 & 0.098 & $* *$ & -0.338 & 0.094 & $* *$ \\
\hline Flag - undefined & -0.449 & 0.202 & $*$ & -0.561 & 0.170 & $* *$ & -0.454 & 0.149 & $* *$ & -0.492 & 0.135 & $* *$ & -0.482 & 0.127 & $* *$ \\
\hline Flag - white & $\mathrm{BM}$ & & & $\mathrm{BM}$ & & & BM & & & $\mathrm{BM}$ & & & BM & & \\
\hline Classification society - IACS & 0.866 & 0.162 & $* *$ & 1.001 & 0.145 & $* *$ & 1.126 & 0.133 & $* *$ & 1.029 & 0.115 & $* *$ & 1.073 & 0.109 & $* *$ \\
\hline Classification society - NIACS & -0.324 & 0.280 & & 0.666 & 0.185 & $* *$ & 0.712 & 0.175 & $* *$ & 0.584 & 0.161 & $* *$ & 0.737 & 0.150 & $* *$ \\
\hline Classification society - Unknown & $\mathrm{BM}$ & & & $\mathrm{BM}$ & & & $\mathrm{BM}$ & & & $\mathrm{BM}$ & & & $\mathrm{BM}$ & & \\
\hline DoC company - EEUR & $\mathrm{n} / \mathrm{a}$ & & & -0.090 & 0.997 & & -0.136 & 0.706 & & 0.567 & 0.379 & & 0.693 & 0.256 & $* *$ \\
\hline DoC company - DEVC & -0.143 & 0.466 & & 0.040 & 0.282 & & 0.105 & 0.200 & & -0.083 & 0.170 & & -0.161 & 0.151 & \\
\hline DoC company - LSDC & 1.193 & 1.019 & & 0.628 & 1.015 & & 0.804 & 0.667 & & 0.800 & 0.568 & & 0.566 & 0.574 & \\
\hline DoC company - Unknown & 1.859 & 0.233 & $* *$ & 1.607 & 0.182 & $* *$ & 1.206 & 0.138 & $* *$ & 0.959 & 0.108 & $* *$ & 0.798 & 0.093 & $* *$ \\
\hline DoC company - OECD & BM & & & $\mathrm{BM}$ & & & $\mathrm{BM}$ & & & $\mathrm{BM}$ & & & $\mathrm{BM}$ & & \\
\hline Earnings (ln) & 0.139 & 0.071 & $\wedge$ & 0.197 & 0.062 & $* *$ & 0.115 & 0.056 & $*$ & 0.085 & 0.053 & & 0.083 & 0.052 & \\
\hline Age: $0-4$ years & BM & & & $\mathrm{BM}$ & & & $\mathrm{BM}$ & & & $\mathrm{BM}$ & & & $\mathrm{BM}$ & & \\
\hline Age: $5-10$ years & -0.337 & 0.281 & & -0.456 & 0.256 & $\wedge$ & -0.405 & 0.246 & & -0.671 & 0.234 & $* *$ & -0.617 & 0.230 & $* *$ \\
\hline Age: $11-15$ years 3 & -1.047 & 0.402 & $* *$ & -0.843 & 0.320 & $* *$ & -0.673 & 0.291 & $*$ & -0.646 & 0.249 & $* *$ & -0.413 & 0.228 & $\wedge$ \\
\hline Age: $16-20$ years & -0.543 & 0.352 & & -0.567 & 0.306 & $\wedge$ & -0.377 & 0.280 & & -0.319 & 0.238 & & -0.269 & 0.234 & \\
\hline Age: $21-25$ years & 2.057 & 0.211 & $* *$ & 2.096 & 0.177 & $* *$ & 2.198 & 0.165 & $* *$ & 2.010 & 0.144 & $* *$ & 2.071 & 0.143 & $* *$ \\
\hline Age: above 25 years & 3.070 & 0.214 & $* *$ & 3.130 & 0.180 & $* *$ & 3.286 & 0.167 & $* *$ & 3.139 & 0.146 & $* *$ & 3.305 & 0.144 & $* *$ \\
\hline Constant & -12.819 & 0.452 & & -12.013 & 0.380 & $* *$ & -11.783 & 0.352 & & -10.988 & 0.320 & & -11.132 & 0.310 & \\
\hline Number of arrivals & 11,061 & & & 11,729 & & & 11,998 & & & 12,418 & & & 12,423 & & \\
\hline
\end{tabular}

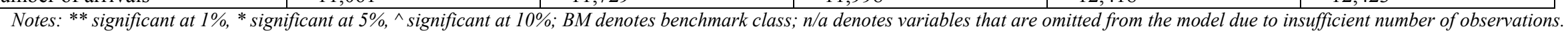


Appendix 1.E: Results of hazard models for passenger vessels

\begin{tabular}{|c|c|c|c|c|c|c|c|c|c|c|c|c|c|c|c|}
\hline \multirow[b]{2}{*}{ Variables } & \multicolumn{3}{|c|}{ Up to $31 / 12 / 2003$} & \multicolumn{3}{|c|}{ Up to $31 / 12 / 2004$} & \multicolumn{3}{|c|}{ Up to $31 / 12 / 2005$} & \multicolumn{3}{|c|}{ Up to $31 / 12 / 2006$} & \multicolumn{3}{|c|}{ Up to $31 / 12 / 2007$} \\
\hline & Coef & SE & Sig & Coef & SE & Sig & Coef & SE & Sig & Coef & SE & Sig & Coef & SE & Sig \\
\hline Tonnage (ln) & 0.041 & 0.086 & & 0.059 & 0.077 & & 0.053 & 0.068 & & 0.071 & 0.062 & & 0.052 & 0.058 & \\
\hline Port state control inspection & $\mathrm{n} / \mathrm{a}$ & & & $\mathrm{n} / \mathrm{a}$ & & & -1.252 & 0.618 & $*$ & -1.117 & 0.471 & $*$ & -1.328 & 0.463 & $* *$ \\
\hline Detained & $\mathrm{n} / \mathrm{a}$ & & & $\mathrm{n} / \mathrm{a}$ & & & 2.227 & 1.078 & $*$ & 1.730 & 0.946 & $\wedge$ & 2.280 & 0.771 & $* *$ \\
\hline Total deficiencies & $\mathrm{n} / \mathrm{a}$ & & & $\mathrm{n} / \mathrm{a}$ & & & -0.175 & 0.246 & & -0.364 & 0.367 & & -0.257 & 0.217 & \\
\hline Change of Flag & 0.877 & 0.493 & $\wedge$ & 1.047 & 0.353 & $* *$ & 0.928 & 0.340 & $* *$ & 0.872 & 0.334 & $* *$ & 0.853 & 0.330 & $*$ \\
\hline Change of DoC company & $\mathrm{n} / \mathrm{a}$ & & & 0.107 & 1.043 & & -0.363 & 1.069 & & -1.138 & 0.717 & & -1.137 & 0.589 & $\wedge$ \\
\hline Less serious casualty (180 days) & $\mathrm{n} / \mathrm{a}$ & & & $\mathrm{n} / \mathrm{a}$ & & & $\mathrm{n} / \mathrm{a}$ & & & $\mathrm{n} / \mathrm{a}$ & & & $\mathrm{n} / \mathrm{a}$ & & \\
\hline Less serious casualty ( 360 days) & $\mathrm{n} / \mathrm{a}$ & & & $\mathrm{n} / \mathrm{a}$ & & & $\mathrm{n} / \mathrm{a}$ & & & $\mathrm{n} / \mathrm{a}$ & & & $\mathrm{n} / \mathrm{a}$ & & \\
\hline Serious casualty (180 days) & $\mathrm{n} / \mathrm{a}$ & & & $\mathrm{n} / \mathrm{a}$ & & & $\mathrm{n} / \mathrm{a}$ & & & $\mathrm{n} / \mathrm{a}$ & & & $\mathrm{n} / \mathrm{a}$ & & \\
\hline Serious casualty (360 days) & $\mathrm{n} / \mathrm{a}$ & & & $\mathrm{n} / \mathrm{a}$ & & & 0.360 & 1.026 & & 0.097 & 1.031 & & -0.006 & 1.036 & \\
\hline Very serious casualty (180 days) & $\mathrm{n} / \mathrm{a}$ & & & $\mathrm{n} / \mathrm{a}$ & & & $\mathrm{n} / \mathrm{a}$ & & & $\mathrm{n} / \mathrm{a}$ & & & $\mathrm{n} / \mathrm{a}$ & & \\
\hline Very serious casualty (360 days) & $\mathrm{n} / \mathrm{a}$ & & & $\mathrm{n} / \mathrm{a}$ & & & $\mathrm{n} / \mathrm{a}$ & & & $\mathrm{n} / \mathrm{a}$ & & & $\mathrm{n} / \mathrm{a}$ & & \\
\hline Flag - black & 1.074 & 0.388 & $* *$ & 1.119 & 0.320 & $* *$ & 0.948 & 0.270 & $* *$ & 1.049 & 0.245 & $* *$ & 1.021 & 0.229 & $* *$ \\
\hline Flag - grey & 0.838 & 0.348 & $*$ & 0.989 & 0.289 & $* *$ & 0.947 & 0.244 & $* *$ & 0.896 & 0.230 & $* *$ & 0.888 & 0.219 & $* *$ \\
\hline Flag - undefined & 0.441 & 0.456 & & 0.453 & 0.382 & & 0.208 & 0.339 & & 0.316 & 0.302 & & 0.288 & 0.285 & \\
\hline Flag - white & $\mathrm{BM}$ & & & $\mathrm{BM}$ & & & $\mathrm{BM}$ & & & $\mathrm{BM}$ & & & $\mathrm{BM}$ & & \\
\hline Classification society - IACS & 0.586 & 0.462 & & 0.610 & 0.388 & & 0.795 & 0.366 & $*$ & 0.695 & 0.316 & $*$ & 0.633 & 0.300 & $*$ \\
\hline Classification society - NIACS & -0.265 & 0.580 & & -0.325 & 0.503 & & 0.247 & 0.428 & & 0.224 & 0.373 & & 0.329 & 0.345 & \\
\hline Classification society - Unknown & $\mathrm{BM}$ & & & BM & & & BM & & & BM & & & BM & & \\
\hline DoC company - EEUR & $\mathrm{n} / \mathrm{a}$ & & & $\mathrm{n} / \mathrm{a}$ & & & 0.850 & 0.845 & & 0.609 & 0.819 & & 0.289 & 0.789 & \\
\hline DoC company - DEVC & $\mathrm{n} / \mathrm{a}$ & & & 1.803 & 1.240 & & 0.599 & 0.686 & & 0.604 & 0.611 & & $\mathrm{n} / \mathrm{a}$ & & \\
\hline DoC company - LSDC & $\mathrm{n} / \mathrm{a}$ & & & $\mathrm{n} / \mathrm{a}$ & & & $\mathrm{n} / \mathrm{a}$ & & & $\mathrm{n} / \mathrm{a}$ & & & 0.464 & 0.545 & \\
\hline DoC company - Unknown & 2.957 & 1.021 & $* *$ & 3.310 & 1.039 & $* *$ & 1.741 & 0.489 & $* *$ & 1.070 & 0.421 & $* *$ & 1.472 & 0.369 & $* *$ \\
\hline DoC company - OECD & $\mathrm{BM}$ & & & $\mathrm{BM}$ & & & BM & & & $\mathrm{BM}$ & & & $\mathrm{BM}$ & & \\
\hline Age: $0-4$ years & $\mathrm{BM}$ & & & $\mathrm{BM}$ & & & $\mathrm{BM}$ & & & $\mathrm{BM}$ & & & $\mathrm{BM}$ & & \\
\hline Age: $5-10$ years & -0.529 & 0.599 & & -0.983 & 0.559 & $\wedge$ & -1.013 & 0.558 & $\wedge$ & -1.150 & 0.558 & $*$ & -1.173 & 0.556 & $*$ \\
\hline Age: $11-15$ years 3 & -0.532 & 0.613 & & -0.739 & 0.519 & & -0.176 & 0.422 & & -0.306 & 0.421 & & -0.336 & 0.419 & \\
\hline Age: $16-20$ years & 0.167 & 0.501 & & -0.168 & 0.434 & & -0.220 & 0.433 & & -0.242 & 0.412 & & -0.162 & 0.397 & \\
\hline Age: $21-25$ years & 0.928 & 0.402 & & 0.530 & 0.341 & & 0.527 & 0.339 & & 0.575 & 0.331 & $\wedge$ & 0.612 & 0.324 & $\wedge$ \\
\hline Age: above 25 years & 0.866 & 0.435 & $*$ & 1.144 & 0.328 & $* *$ & 1.520 & 0.300 & $* *$ & 1.548 & 0.284 & $* *$ & 1.667 & 0.276 & $* *$ \\
\hline Constant & -9.546 & 1.466 & & -9.864 & 1.413 & & -8.430 & 0.968 & & -8.442 & 0.851 & & -8.054 & 0.798 & $* *$ \\
\hline Number of arrivals & 2,430 & & & 2,519 & & & 2,578 & & & 2,610 & & & 2,610 & & \\
\hline
\end{tabular}

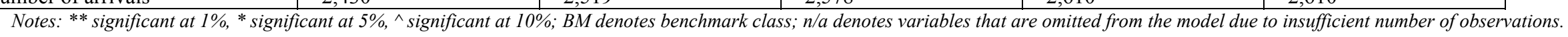




\section{Appendix 2: Logit models for adjusting TIV}

TIV represents the total insured value for a life ending incident, that is, a $100 \%$ loss, and consists of the five components described in Section 2. Most total loss incidents, however, entail a claim of only a part of the total TIV, consisting of partial claims on each of the five components. The spread across the components of TIV is difficult to estimate, since historical data are either not available or not readily disclosed within the marine insurance industry. For this reason, we estimate the probability of occurrence of each of the five risk components, conditional on the information that an accident occurred. We estimate the probabilities of incidents with (1) damage to hull or machinery (HM), (2) loss of life (LL) for passenger vessels, (3) pollution (POL) for oil tankers, (4) third party liability (TPL), and (5) cargo damage (CAR). For this purpose, we employ what we call the "Type B models" to obtain the five relevant conditional probabilities. The estimates are based on all observations involving casualties, regardless of the seriousness of the incident. The casualty dataset is aggregated to obtain a single observation per ship, with corresponding sample average values of the covariates.

The dependent variable in our Type B models is binary, as the ship either has a "casualty" ${ }^{20 \text { " (denoted }}$ by " 1 ") or "no casualty" (denoted by " 0 "). For each ship in the dataset, the probability of an accident $(P)$ is modelled in terms of the explanatory factors $(X)$ by means of the so-called logit model. Let the term $X \beta$ denote the weighted average (with weights $\beta$ ) of the explanatory variables that apply for this ship. The basic model for the casualty probability is given by $\mathrm{P}=\exp (\mathrm{X} \beta) /(1+\exp (\mathrm{X} \beta))$, where

$$
X \beta=\beta_{0}+\sum_{\mathrm{k}=1}^{4} \beta_{1, k} \mathrm{ST}_{k}+\beta_{2} \ln (1+\mathrm{AGE})+\beta_{3} \ln (\mathrm{GRT})+\sum_{\mathrm{k}=1}^{3} \beta_{4, k} \mathrm{FL}_{k}+\sum_{\mathrm{k}=1}^{2} \beta_{5, k} \mathrm{CL}_{k}+\beta_{6} \ln (\mathrm{EARN})
$$

In this expression, ST denotes the ship type (5 categories), AGE is the age of the vessel at the time of incident, GRT is the tonnage of vessel, FL denotes the flag state group (with the same 4 categories as used in the Type A models), CL denotes the classification society group (with the same 3 categories as used in the Type A models), and EARN are average earnings per day at the time of incident. The ship type, flag, and classification society are categorical variables, which are modelled by means of indicator variables. For example, for the ship type, suppose that general cargo is chosen as reference class, and let the other ship types be numbered as $\mathrm{k}=1$ for dry bulk, $\mathrm{k}=2$ for container, $\mathrm{k}=3$ for tanker, and $\mathrm{k}=4$ for passenger. For a container ship, $\mathrm{ST}_{2}=1$ and $\mathrm{ST}_{1}=\mathrm{ST}_{3}=\mathrm{ST}_{4}=0$, so that $\sum_{k=1}^{4} \beta_{k} S T_{k}=\beta_{2}$, so that $\beta_{2}$ is the effect of a container ship as compared to a general cargo vessel. The logit models are estimated by quasi-maximum likelihood, see Greene [35]. This method allows for possible misspecification of the assumed underlying (logistic) distribution function. Table 2.A shows average values of the probabilities per casualty type and per ship type, as well as some summary statistics.

Table 2.A: Average probabilities of type B models and model summary statistics

\begin{tabular}{|l|r|r|r|r|r|}
\hline TIV component & HM & LL & POL & TPL & CAR \\
\hline General cargo & 0.575 & $\mathrm{n} / \mathrm{a}$ & $\mathrm{n} / \mathrm{a}$ & 0.424 & 0.110 \\
Dry bulk & 0.593 & $\mathrm{n} / \mathrm{a}$ & $\mathrm{n} / \mathrm{a}$ & 0.389 & 0.098 \\
Container & 0.497 & $\mathrm{n} / \mathrm{a}$ & $\mathrm{n} / \mathrm{a}$ & 0.414 & 0.164 \\
Tanker & 0.605 & $\mathrm{n} / \mathrm{a}$ & 0.074 & 0.328 & 0.123 \\
Passenger vessel & 0.744 & 0.015 & $\mathrm{n} / \mathrm{a}$ & 0.289 & $\mathrm{n} / \mathrm{a}$ \\
\hline McFadden R2 & 0.018 & 0.042 & 0.078 & 0.015 & 0.026 \\
Total Hit Rate (\% correct) & 55.75 & 97.84 & 65.83 & 53.36 & 60.93 \\
HL-Statistic (prob. value) & 0.775 & 0.394 & 0.389 & 0.680 & 0.649 \\
\hline
\end{tabular}

Note: "n/a" denotes "not applicable" for the calculation of TECS.

\footnotetext{
${ }^{20}$ The classification of casualties involving cargo damage and third party liability is not straightforward for the data obtained from the data providers. Therefore, the data have been reclassified manually. Another challenge is the determination of incidents involving pollution, as the type of pollution is not well defined. As concerns the TIV components in the calculation of TECS, for passenger vessels we account only for the probability of loss of life (instead of the cargo values), and for oil tankers we account only for pollution.
} 
Appendix 3.A: TECS per ship type and age group (in thousands of USD)

\begin{tabular}{|c|c|c|c|c|c|}
\hline \multirow[b]{2}{*}{ Ship type } & \multirow[b]{2}{*}{ Age group (year) } & \multicolumn{2}{|c|}{ Upper bound } & \multicolumn{2}{|c|}{ Lower bound } \\
\hline & & Mean & Median & Mean & Median \\
\hline \multirow[t]{7}{*}{ General cargo } & all & 202.4 & 44.1 & 110.6 & 21.0 \\
\hline & up to 5 & 62.9 & 20.0 & 32.3 & 10.0 \\
\hline & 6 to 10 & 64.4 & 21.8 & 33.4 & 11.0 \\
\hline & 11 to 15 & 55.6 & 23.0 & 28.6 & 11.4 \\
\hline & 16 to 20 & 95.2 & 35.4 & 49.1 & 17.3 \\
\hline & 21 to 25 & 378.7 & 163.5 & 201.0 & 82.6 \\
\hline & above 25 & 641.2 & 154.9 & 367.8 & 89.0 \\
\hline \multirow[t]{7}{*}{ Dry bulk } & all & 158.7 & 36.3 & 87.0 & 18.6 \\
\hline & up to 5 & 45.7 & 21.2 & 20.8 & 9.5 \\
\hline & 6 to 10 & 33.7 & 11.4 & 15.7 & 5.2 \\
\hline & 11 to 15 & 34.2 & 14.1 & 16.0 & 6.6 \\
\hline & 16 to 20 & 133.6 & 50.0 & 63.8 & 23.1 \\
\hline & 21 to 25 & 383.9 & 116.6 & 179.4 & 54.6 \\
\hline & above 25 & 351.3 & 76.6 & 165.2 & 33.7 \\
\hline \multirow[t]{7}{*}{ Container } & all & 98.4 & 22.4 & 46.0 & 9.9 \\
\hline & up to 5 & 45.7 & 21.2 & 20.8 & 9.5 \\
\hline & 6 to 10 & 33.7 & 11.4 & 15.7 & 5.2 \\
\hline & 11 to 15 & 34.2 & 14.1 & 16.0 & 6.6 \\
\hline & 16 to 20 & 133.6 & 50.0 & 63.8 & 23.1 \\
\hline & 21 to 25 & 383.9 & 116.6 & 179.4 & 54.6 \\
\hline & above 25 & 351.3 & 76.6 & 165.2 & 33.7 \\
\hline \multirow[t]{7}{*}{ Tanker } & all & 201.4 & 61.3 & 71.7 & 21.3 \\
\hline & up to 5 & 128.0 & 51.1 & 44.4 & 17.2 \\
\hline & 6 to 10 & 133.2 & 56.2 & 48.0 & 19.3 \\
\hline & 11 to 15 & 110.2 & 70.2 & 40.5 & 25.1 \\
\hline & 16 to 20 & 114.1 & 49.1 & 40.4 & 17.0 \\
\hline & 21 to 25 & 818.5 & 319.9 & 297.5 & 111.2 \\
\hline & above 25 & $1,185.1$ & 433.3 & 406.1 & 147.7 \\
\hline \multirow[t]{7}{*}{ Passenger } & all & 533.3 & 550.2 & 34.4 & 34.1 \\
\hline & up to 5 & 596.1 & 631.4 & 35.3 & 34.9 \\
\hline & 6 to 10 & 558.8 & 592.7 & 34.7 & 34.7 \\
\hline & 11 to 15 & 503.6 & 529.8 & 32.4 & 34.3 \\
\hline & 16 to 20 & 458.2 & 495.0 & 35.6 & 35.3 \\
\hline & 21 to 25 & 329.7 & 358.2 & 27.0 & 25.1 \\
\hline & above 25 & 334.3 & 287.6 & 34.0 & 20.2 \\
\hline
\end{tabular}

Note: The mean and median values are based on all observations in the dataset. 
Appendix 3.B: TECS per ship type and size group (in thousands of USD)

\begin{tabular}{|c|c|c|c|c|c|}
\hline \multirow[b]{2}{*}{ Ship type } & \multirow[b]{2}{*}{ Size group (gt) } & \multicolumn{2}{|c|}{ Upper bound } & \multicolumn{2}{|c|}{ Lower bound } \\
\hline & & Mean & Median & Mean & Median \\
\hline \multirow[t]{7}{*}{ General cargo } & all & 202.4 & 44.1 & 110.6 & 21.0 \\
\hline & below 10,000 & 45.7 & 20.1 & 21.2 & 9.0 \\
\hline & 10,001 to 20,000 & 184.9 & 32.5 & 102.5 & 16.3 \\
\hline & 20,001 to 30,000 & 281.3 & 57.9 & 157.6 & 30.1 \\
\hline & 30,001 to 40,000 & 286.2 & 81.9 & 158.2 & 41.8 \\
\hline & 40,001 to 50,000 & 221.4 & 46.4 & 116.9 & 23.9 \\
\hline & above 50,000 & 251.4 & 65.4 & 131.6 & 33.2 \\
\hline \multirow[t]{7}{*}{ Dry bulk } & all & 158.7 & 36.3 & 87.0 & 18.6 \\
\hline & below 10,000 & 84.9 & 57.8 & 36.7 & 23.4 \\
\hline & 10,001 to 20,000 & 62.0 & 12.2 & 31.6 & 5.9 \\
\hline & 20,001 to 30,000 & 158.4 & 26.0 & 92.8 & 13.2 \\
\hline & 30,001 to 40,000 & 125.6 & 36.9 & 67.5 & 19.1 \\
\hline & 40,001 to 50,000 & 123.8 & 34.4 & 65.4 & 18.2 \\
\hline & above 50,000 & 282.3 & 86.6 & 154.1 & 46.7 \\
\hline \multirow[t]{7}{*}{ Container } & all & 98.4 & 22.4 & 46.0 & 9.9 \\
\hline & below 10,000 & 27.9 & 14.3 & 11.5 & 5.9 \\
\hline & 10,001 to 20,000 & 39.2 & 11.5 & 18.0 & 5.1 \\
\hline & 20,001 to 30,000 & 76.4 & 15.2 & 35.4 & 6.9 \\
\hline & 30,001 to 40,000 & 126.3 & 35.4 & 59.4 & 16.3 \\
\hline & 40,001 to 50,000 & 133.5 & 35.7 & 63.1 & 16.3 \\
\hline & above 50,000 & 139.9 & 29.6 & 66.0 & 13.5 \\
\hline \multirow[t]{7}{*}{ Tanker } & all & 201.4 & 61.3 & 71.7 & 21.3 \\
\hline & below 10,000 & 34.2 & 12.9 & 10.7 & 3.4 \\
\hline & 10,001 to 20,000 & 119.6 & 30.0 & 39.7 & 9.6 \\
\hline & 20,001 to 30,000 & 126.9 & 54.3 & 44.4 & 18.2 \\
\hline & 30,001 to 40,000 & 245.7 & 62.9 & 91.8 & 22.4 \\
\hline & 40,001 to 50,000 & 264.4 & 96.3 & 95.4 & 35.3 \\
\hline & above 50,000 & 312.4 & 127.5 & 109.1 & 45.9 \\
\hline \multirow[t]{7}{*}{ Passenger } & all & 533.3 & 550.2 & 34.4 & 34.1 \\
\hline & below 10,000 & 131.1 & 63.7 & 16.0 & 10.9 \\
\hline & 10,001 to 20,000 & 219.7 & 244.2 & 15.9 & 16.4 \\
\hline & 20,001 to 30,000 & 207.1 & 173.3 & 22.6 & 16.9 \\
\hline & 30,001 to 40,000 & 583.2 & 627.1 & 44.1 & 39.3 \\
\hline & 40,001 to 50,000 & 417.4 & 436.5 & 27.5 & 24.1 \\
\hline & above 50,000 & 605.2 & 613.3 & 34.7 & 34.8 \\
\hline
\end{tabular}

Note: The mean and median values are based on all observations in the dataset. 